\title{
Effects of dietary nutrients on volatile breath metabolites
}

\author{
Olawunmi A. Ajibola ${ }^{1}$, David Smith ${ }^{1}$, Patrik Španěl ${ }^{1,2}$ and Gordon A. A. Ferns ${ }^{3} *$ \\ ${ }^{1}$ Guy Hilton Research Centre, Institute for Science and Technology in Medicine, University of Keele, Thornburrow Drive, Hartshill, \\ Stoke-on-Trent ST4 7QB, UK \\ ${ }^{2}$ J. Heyrovsky Institute of Physical Chemistry, Academy of Sciences of the Czech Republic, Dolejskova 3, 182 23, Prague 8, Caech Republic \\ ${ }^{3}$ Division of Medical Education, Brighton and Sussex Medical School, Mayfield House, University of Brighton, Brighton BN1 9PH, UK
}

(Received 13 January 2013 - Final revision received 22 July 2013 - Accepted 25 July 2013)

Journal of Nutritional Science (2013), vol. 2, e34, page 1 of 15

doi:10.1017/jns.2013.26

Abstract

Breath analysis is becoming increasingly established as a means of assessing metabolic, biochemical and physiological function in health and disease. The methods available for these analyses exploit a variety of complex physicochemical principles, but are becoming more easily utilised in the clinical setting. Whilst some of the factors accounting for the biological variation in breath metabolite concentrations have been clarified, there has been relatively little work on the dietary factors that may influence them. In applying breath analysis to the clinical setting, it will be important to consider how these factors may affect the interpretation of endogenous breath composition. Diet may have complex effects on the generation of breath compounds. These effects may either be due to a direct impact on metabolism, or because they alter the gastrointestinal flora. Bacteria are a major source of compounds in breath, and their generation of $\mathrm{H}_{2}$, hydrogen cyanide, aldehydes and alkanes may be an indicator of the health of their host.

Key words: Breath analysis: Selected ion flow tube-MS: Macronutrients: Micronutrients: Gut flora

\section{Historical background}

The relationship between breath composition and health has been known for many centuries. More than 2500 years ago, the Greek physician, Hippocrates of Cos noted the importance of breath smell in the diagnosis of liver disease, using the term 'foetor hepaticus' to describe the characteristic breath odour associated with liver failure (Treatise on Breath Odour and Disease, 5th century BC).

The ancient Persian physician and philosopher, Ibn Sina (Avicenna) wrote that '...it is the role of the vital force (breath) to maintain a perfect equilibrium within the elements of the body, and between the elements of the body and the environment' (The Canon of Medicine, 10th century). An important environmental determinant of breath composition is diet. Approximately 40 years ago, Pauling et $a l^{(1)}$ investigated the relationship between breath composition and diet and recognised the potential impact of intestinal flora as a contributing factor to breath composition. Individuals were placed on a defined elemental diet, consisting almost entirely of small molecules that the authors assumed would be absorbed from the upper gastrointestinal tract, and that intestinal flora would be reduced in the lower gastrointestinal tract because of the lack of nutrients reaching them. Using temperatureprogrammed gas-liquid partition chromatography, the quantitative determination of about 250 substances in a sample of human breath was possible at that time.

\section{Introduction}

Today, using exquisitely sensitive analytical techniques, more than 500 compounds have been reproducibly identified in exhaled breath $^{(2)}$, though as many as 3000 different compounds

Abbreviations: ppbv, parts per billion by volume; PTR, proton transfer reaction; SIFT, selected ion flow tube; VOC, volatile organic compounds.

* Corresponding author: Professor Gordon Ferns, email g.ferns@bsms.ac.uk 
Table 1. Established and emerging clinical applications of breath analysis

\begin{tabular}{|c|c|}
\hline Breath analysis & References \\
\hline Breath $\mathrm{H}_{2}$ test for carbohydrate metabolism & $\begin{array}{l}\text { Rumessen et al. } .^{(137)} \text {; Romagnuolo et al. }{ }^{(138)} \text {; Eisenmann } \\
\text { et al. }{ }^{(139)} \text {; Bond \& Levitt et al. }{ }^{(140,141)}\end{array}$ \\
\hline Breath $\mathrm{NO}$ test to monitor therapy for asthma & Eisenmann et al. ${ }^{(139)} ;$ Taylor et al. ${ }^{(142)}$ \\
\hline Breath $\mathrm{CO}$ test for neonatal jaundice & Stevenson et al. ${ }^{(143)}$ \\
\hline Breath test for diagnosis of Helicobacter pylori & Romagnuolo et al. ${ }^{(138)}$ \\
\hline Breath test for heart transplant rejection & Phillips et al. ${ }^{(144)}$ \\
\hline Breath $\mathrm{NH}_{3}$ has been identified as an indicator of the efficacy of renal dialysis & Endre et al. ${ }^{(145)}$; Rolla et al. ${ }^{(146)}$; Narasimhan et al. ${ }^{(147)}$ \\
\hline $\begin{array}{l}\text { Breath } \mathrm{H}_{2} \text { and the }{ }^{13} \mathrm{CO}_{2}:{ }^{12} \mathrm{CO}_{2} \text { ratio (following the ingestion of }{ }^{13} \mathrm{C} \text {-labelled compounds) as } \\
\text { related to gastric emptying and bowel transit times }\end{array}$ & $\begin{array}{l}\text { Bond \& Levitt et al. }{ }^{(141)} \text {; Braden et al. } .^{(148)} \text {; Rao et al. }{ }^{(149)} \text {; } \\
\text { Geboes et al. }{ }^{(150)}\end{array}$ \\
\hline $\begin{array}{l}\text { Hydrogen cyanide is released by the pathogen, Pseudomonas aeruginosa, and the } \\
\text { detection of high concentrations of hydrogen cyanide in breath may be used for the early } \\
\text { detection of bacterial infection of children with cystic fibrosis }\end{array}$ & Shestivska et al..$^{(151)}$; Carroll et al. ${ }^{(152)}$ \\
\hline
\end{tabular}

have been sporadically detected in breath of different individuals ${ }^{(3,4)}$. It is now possible to measure volatile organic compounds (VOC) in breath with great sensitivity (down to parts per billion by volume; ppbv) and specificity, using MS and related analytical methods. As a consequence, breath analysis now has a number of well-established clinical applications ${ }^{(5)}$ (Table 1). It also has enormous potential value in metabolic research, particularly when combined with stable isotope labelling. It has, for example, been used in kinetic studies of amino acid metabolism ${ }^{(6)}$. Breath analysis may also be used for applications that would otherwise be difficult using other techniques, for example in the assessment of whole-body oxidative stress ${ }^{(7)}$, or cholesterol biosynthesis ${ }^{(8)}$. Breath analysis may also be a useful adjunct to blood and faecal analysis in the investigation of gut $_{\text {microbiota }}{ }^{(9)}$. The present review briefly outlines the physiological and dietary factors that may have an important impact on breath compounds and the methods used for assessing them, together with the reported concentrations of these compounds in health and disease.

\section{Sources of volatile metabolites in exhaled breath}

Volatile metabolites in exhaled breath are derived from several sources: they may be derived from the environmental inspired air, from cells, including micro-organisms that are located throughout the oral/nasal cavities and the pulmonary system, the upper and lower gastrointestinal tracts and from general human metabolism (Fig. 1) ${ }^{(10-12)}$. For example, NO is present
Effects on gut transit

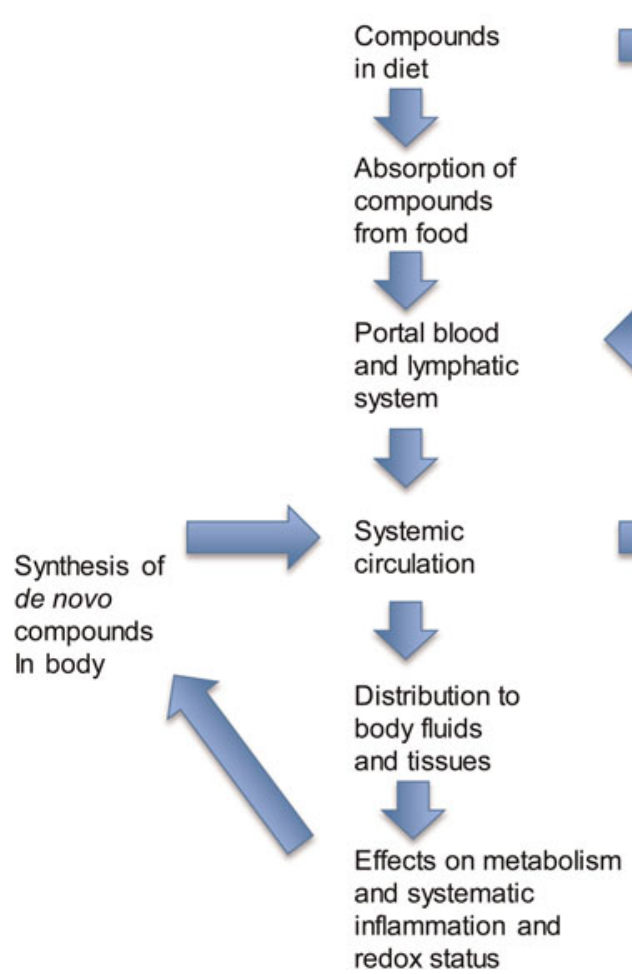

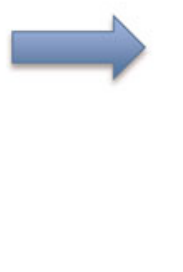

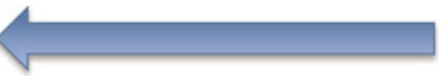

Effects on flora in oro-pharynx, oesophagus and stomach

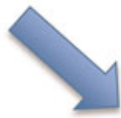

Gut floraderived metabolites

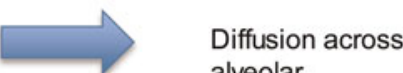
alveolar membrane

\section{Effects on} gut transit

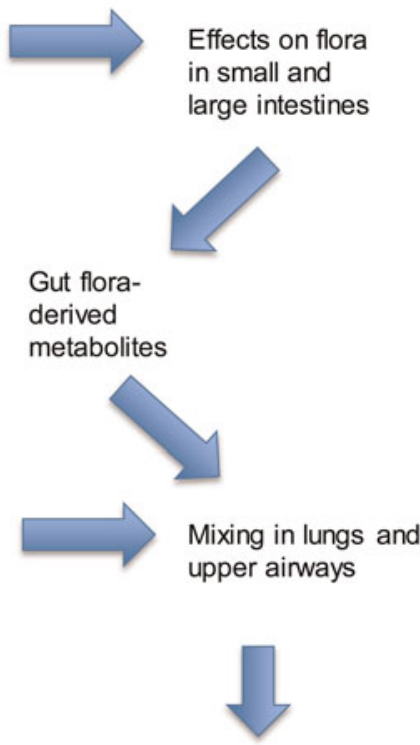

Compounds in expired air

Fig. 1. The complex interactions between diet and expired breath metabolites. 
in trace amounts in atmospheric air and is therefore present in the inspired air; it is also an important biological mediator in the vasculature ${ }^{(13)}$, being derived from the action of $\mathrm{NO}$ synthase on the amino acid arginine, and is elaborated at high concentrations by activated inflammatory cells ${ }^{(14)}$. Its concentrations in expired air can therefore be considerably higher than in inspired air, and may be derived from several sources.

\section{Physiological variations in breath composition}

\section{Site of exhaled breath sampling}

The measured concentrations of several exhaled breath constituents differ significantly depending on their site of breath sampling; whether from the mouth, nose, or the static oral cavity. Some of these compounds, for example $\mathrm{NH}_{3}$, ethanol and hydrogen cyanide, are predominantly generated in the oral cavity in healthy subjects ${ }^{(15,16)}$. Hence oral health, including periodontal and dental disease, are potential confounding factors ${ }^{(17)}$. It has been shown that concentrations of some compounds in the exhaled breath, for example $\mathrm{NH}_{3}$ and ethanol, can be increased by sugar and urea mouth washes ${ }^{(18)}$. Hence, without careful preparation, mouth production of these and other compounds can compromise the quantification of endogenous trace compounds present in the alveolar breath. However, the concentrations of both the urea and sucrose solutions used in these latter studies that proved the enhancement of $\mathrm{NH}_{3}$ and ethanol levels were greater than normally present in food and beverages; thus in most situations such severe enhancements will not occur ${ }^{(18)}$. It is also possible to simultaneously monitor mouth and nasal concentrations of breath compounds to elucidate their source ${ }^{(19)}$. Furthermore, it is possible to sample end-tidal gas only ${ }^{(20)}$ by physically filtering out gas from the oral cavity (for example, by using buffered end-tidal sampling), or by data processing post hoc ${ }^{(20,21)}$.

\section{Determinants of inter-individual and intra-individual variation}

Intra-individual studies that have been carried out over about $30 \mathrm{~d}$ have revealed the temporal variations in the concentrations of several common breath metabolites for several individuals, including: $\mathrm{NH}_{3}$, acetone, isoprene, ethanol and acetaldehyde ${ }^{(11,22)}$. Breath $\mathrm{NH}_{3}$, acetone and isoprene concentrations were reported to have CV of typically 0.3 over this period. No obvious correlations were found in the distributions of these particular metabolites, except that the $\mathrm{NH}_{3}$ levels were greatest in the breath of the oldest subjects ${ }^{(22)}$. In population (inter-individual) studies over a longer timeframe (6 months), breath methanol levels appeared to have a log-normal distribution for the study population, and did not correlate with age, breath ethanol or ethanol consumed in the previous $24 \mathrm{~h}$; however, there was an inverse correlation with $\mathrm{BMI}^{(23)}$. Breath $\mathrm{NH}_{3}$ increased with age, and a weak but significant correlation between breath propanol and acetone levels was reported ${ }^{(24)}$. Breath isoprene concentrations have been studied in healthy schoolchildren between 7 and 18 years of age, and in this group there was a strong positive association with age ${ }^{(25)}$, possibly related to growth, or steroid hormone biosynthesis.

\section{Fasting and the acute effects of feeding on breath content}

Effects of the fasted or fed state on breath constituents are complex. Breath acetone, $\mathrm{NH}_{3}$, ethanol, isoprene and methanol have been measured during single exhalations whilst fasting and following feeding with a liquid protein-energy meal ${ }^{(26)}$. Breath acetone concentrations fell from a maximum during fasting, reaching their nadir between 4 and $5 \mathrm{~h}$ after feeding. Changes in breath $\mathrm{NH}_{3}$ concentrations were biphasic, possibly related to changes in portal blood flow, with a rapid fall to approximately $50 \%$ of their fasting levels before rising to two or three times their baseline values at $5 \mathrm{~h}^{(26)}$. A brief increase in breath ethanol concentrations was found after feeding, and this is probably related to the ethanol content of some foods. Subsequently, breath ethanol levels remained low throughout the experimental period. Isoprene concentrations did not change significantly ${ }^{(26)}$. Levels of breath ethanol increased if a sweet drink or food had been consumed within $2 \mathrm{~h}$ before providing a breath sample, but surprisingly no increase in breath ethanol was apparent when modest alcohol consumption had occurred the previous evening. Endogenous breath ethanol and acetaldehyde levels were not significantly correlated with each other ${ }^{(27)}$. It has recently been reported that breath hydrogen cyanide may rise following the consumption of food or drink ${ }^{(28)}$.

\section{Effect of exercise and the breath cycle on breath content}

Alveolar breath isoprene and methyl acetate have been reported to increase immediately after moderate exercise, returning to baseline soon thereafter ${ }^{(29,30)}$. We have recently reported that breath isoprene concentrations rise rapidly after commencing exercise, and then decrease during the period of exercise. Plasma cholesterol levels were not obviously correlated with isoprene concentration in breath. Also, isoprene levels were not found to be directly related to sex, age or BMI in this study of adults ${ }^{(30)}$. The changes in breath isoprene during exercise have been attributed to changes in tissue fractional perfusion ${ }^{(31)}$, and the changes in expiratory breath $\mathrm{NO}$ observed during exercise have been reported to be due to changes in air flow rate, rather than increased NO production ${ }^{(32)}$. The exercise-related changes in $\mathrm{NH}_{3}$ concentrations in breath exhaled via the nose appear to vary with age, with a several-fold increase in concentrations persisting into the post-exercise period ${ }^{(31)}$. These changes may be dependent on renal function. Breath composition changes during the breathing cycle. For example, the variation observed in breath acetone appears to be dependent on exhaled volume, but not flow ${ }^{(33)}$.

Molecules directly or indirectly derived from food, beverages and medicines

Following the ingestion of some compounds, there are wide inter-individual variations in their appearance in the breath. 
For example, following the ingestion of eucalyptol, a constituent of proprietary medications, its appearance in breath varies between 1 and $5 \mathrm{~h}$ after ingestion, showing wide inter-subject variations too $^{(34)}$. Green tea was very effective in reducing volatile sulfur compounds (hydrogen sulfide and methyl sulfide) in mouth breath, this being attributed to its disinfectant properties $^{(35)}$. The kinetics of the acute release of aromas from food or beverages is complex, being dependent on the physiological processes involved in swallowing, the lipid content of the food ${ }^{(36)}$ and the vapour pressure of the compound ${ }^{(37)}$. There are a number of volatile compounds in food that may rapidly appear in the breath following their consumption ${ }^{(38-40)}$.

\section{Breath alkanes, smoking, other causes of oxidant stress and} dietary antioxidants

Smoking is known to induce a state of oxidative stress that is associated with lipid peroxidation ${ }^{(41,42)}$ and has been shown to be associated with substantial changes in breath composition $^{(43)}$. Oxidative stress has the potential to damage cells, tissues and organs via the production of reactive oxygen species such as superoxide, $\mathrm{H}_{2} \mathrm{O}_{2}$ and the hydroxyl radical ${ }^{(44)}$. Oxidative stress may be estimated through breath measurements of biomarkers that include ethane, ethylene and pentane ${ }^{(45-52)}$. Although these hydrocarbons only represent a small and possibly variable proportion of the total amount of peroxidised PUFA, their determination in exhaled breath enables an assessment of oxidative stress in vivo ${ }^{(53)}$. Do et al. ${ }^{(54)}$ have previously reported that non-smokers have very low baseline levels of ethane, whilst ethane production correlated with active (packs per d) and lifelong (pack-years) tobacco consumption. Miller et al. ${ }^{(55)}$ have reported similar findings and also report that breath ethane concentrations are related to the time interval between the last cigarette smoked and breath sampling. Do et al. ${ }^{(54)}$ have also shown that antioxidant vitamin supplementation resulted in attenuation of smoking-related lipid peroxidation with a significant decrease in breath ethane production. Aghdassi \& Allard ${ }^{(45)}$ assessed oxidative stress using breath alkane output and other markers of lipid peroxidation in several conditions associated with inflammation, including smoking. Lipid peroxidation was significantly higher and antioxidant vitamin status significantly lower in smokers compared with nonsmokers. $\beta$-Carotene or vitamin E supplementation significantly reduced lipid peroxidation, whilst vitamin $\mathrm{C}$ supplementation had no significant effect. These findings are consistent with those of Hoshino et al. ${ }^{(56)}$ and Allard et al. ${ }^{(57)}$.

In an animal model of vitamin E deficiency, the increased peroxidation of tissue lipids leads to an increased level of breath pentane ${ }^{(58)}$. However, in their paper, Gelmont et al. ${ }^{(58)}$ reported that pentane production was also dependent on dietary linoleate. Breath pentane in the study animals was reduced by removal of linoleate from their diet, by starvation, antibiotic treatment or the addition of vitamin $C$ to their food or water. Breath pentane was increased by the removal of vitamin $\mathrm{E}$ from the diet. The authors concluded that intestinal bacteria were a major source of breath pentane in addition to endogenous membrane lipid peroxidation ${ }^{(58)}$. In recent studies we have found, using selected ion flow tube (SIFT)-MS, that breath pentane is elevated in patients with inflammatory bowel disease such as ulcerative colitis ${ }^{(59)}$.

The effects of a restricted-energy diet have also been investigated in the rat model ${ }^{(60)}$. A significant decrease in ethane generation was found in the rats receiving an energy-restricted diet compared with those fed ad libitum, supporting the hypothesis that energy restriction reduces the level of oxidative stress $^{(61)}$.

Breath pentane is derived from the oxidation of $n-3$ and $n-6$ fatty acids which appear to be transferred from mother to fetus during pregnancy ${ }^{(62)}$. However, in women in their last trimester, who have smoked during pregnancy, it has been reported that breath ethane was higher than for a control group of nonsmokers, and inversely related to serum vitamin $C^{(63)}$. Dietary $n$-3 fatty acid supplementation also appeared to increase lipid peroxidation as assessed by breath alkane output, and this was not prevented by co-administration of vitamin $\mathrm{E}^{(64)}$.

\section{Dietary studies}

The effects of dietary constituents on breath composition are complex, as alluded to in Fig. 2. The acute effects of diet on breath have been described briefly above. Mediumand longer-term effects may be mediated by changes of flora in the gastrointestinal tract ${ }^{(65,66)}$ and direct or indirect effects on gastro-caecal transit time ${ }^{(67,68)}$, together with effects on metabolism, systemic inflammation ${ }^{(69-71)}$ and redox state $^{(72,73)}$.

\section{Effects of macronutrients and dietary energy restriction}

High- and low-fat diets. Rosenkranz et al. ${ }^{(74)}$ have investigated the acute effects of a high-fat meal on pulmonary function and expiratory NO. They found that a high-fat meal was associated with increased expiratory $\mathrm{NO}$, but had no effect on a systemic marker of inflammation, or pulmonary function in normal individuals, and the authors concluded that a high-fat diet may contribute to inflammation within the airway. Studies in patients with asthma have found that a diet containing a high $n-6: n-3$ fatty acid ratio was associated with worsening of asthma control and higher concentrations of NO in exhaled breath ${ }^{(75)}$.

Ketogenic diets are high in fat, low in carbohydrate and contain adequate levels of protein. Under these conditions fat is metabolised in preference to carbohydrates, and ketone bodies (acetone, acetoacetate and $\beta$-hydroxybutyrate) are generated in the liver, leading to ketosis ${ }^{(76)}$. In these circumstances, expiratory breath acetone concentrations are increased substantially. Even in healthy subjects, breath acetone has been reported to rise more than five-fold following a ketogenic diet ${ }^{(77,78)}$. Breath acetone appears to be indicative of systemic ketosis associated with a ketogenic diet ${ }^{(77,79)}$. Under certain circumstances acetone is reduced to isopropanol by hepatic alcohol dehydrogenase and this then also appears in the breath ${ }^{(80)}$. 


\section{Complex carbohydrates}

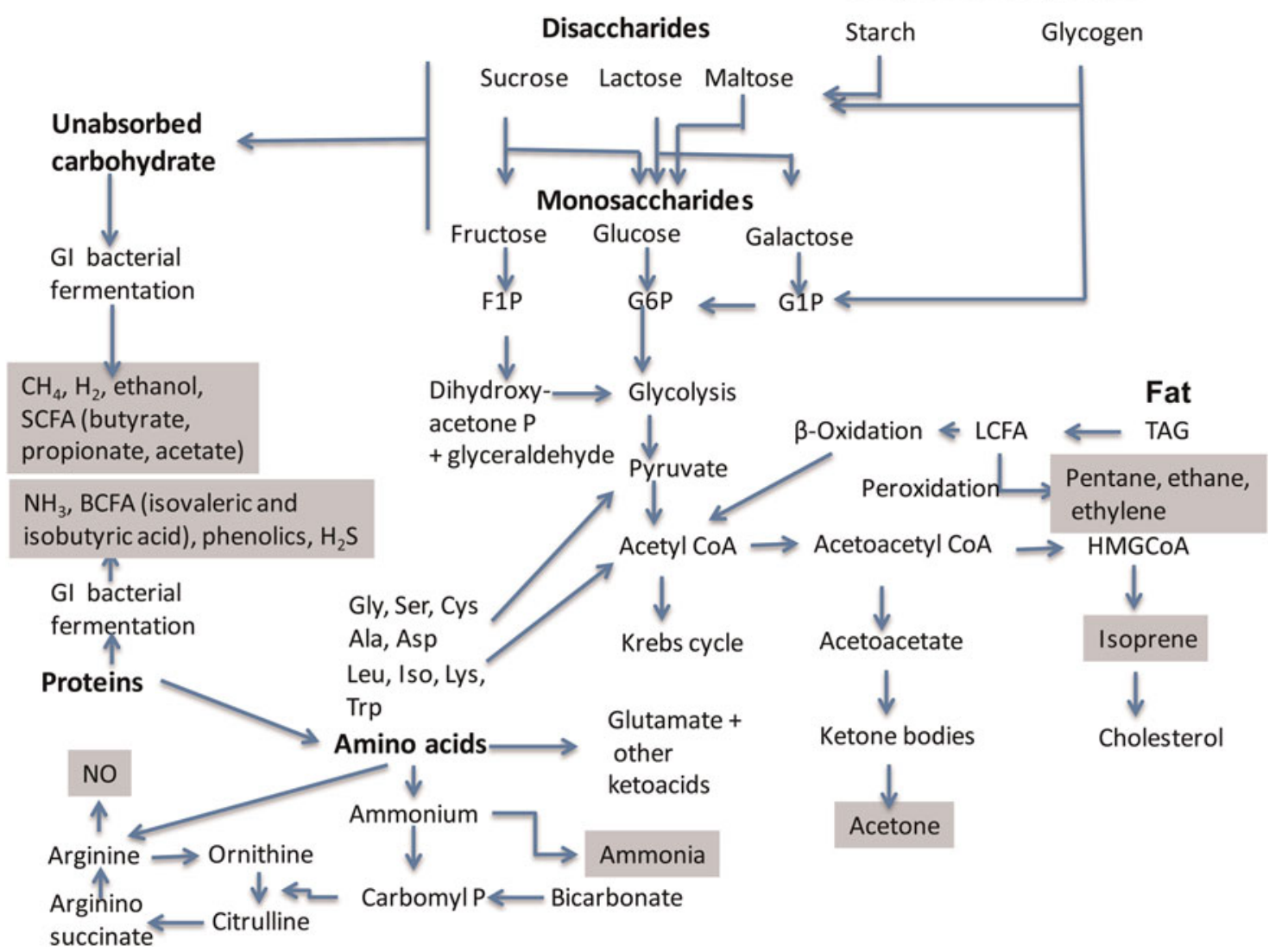

Fig. 2. Dietary and metabolic sources of the major metabolites in human breath. GI, gastrointestinal; F1P, fructose 1-phosphate; G6P, glucose 6-phosphate; G1P, glucose 1-phosphate; LCFA, long-chain fatty acids; BCFA, branched-chain fatty acids; HMG, hydroxy methyl glutaryl; carbomyl P, carbomyl phosphate. The grey boxes represent compounds that have been identified in breath.

Simple carbohydrates and alcohol. $\mathrm{H}_{2}$ breath tests have been used for the assessment of carbohydrate malabsorption and abnormal bacterial colonisation of the gut for many years ${ }^{(81)}$. Basal breath $\mathrm{H}_{2}$ is dependent on dietary carbohydrate ${ }^{(82)} \cdot \mathrm{H}_{2}$ production in man is primarily dependent upon the delivery of ingested, fermentable substrates to an abundant intestinal flora that is normally present only in the colon. In the normal intestine, more than $99 \%$ of $\mathrm{H}_{2}$ production appears to be of colonic origin, but small-bowel production may be increased in a patient with excessive numbers of small-bowel bacteria. $\mathrm{H}_{2}$ breath tests are based on the fact that there is no source for $\mathrm{H}_{2}$ gas in humans other than bacterial metabolism of carbohydrates. Respiratory $\mathrm{H}_{2}$ excretion can therefore be used as an indicator of intestinal $\mathrm{H}_{2}$ production. In carbohydrate tolerance tests, different carbohydrates are administered orally and the concentration of $\mathrm{H}_{2}$ is measured in expired air. When defective sugar absorption is present, unabsorbed sugars are available in the colon for bacterial fermentation $^{(83,84)}$. Approximately $14 \%$ of the total $\mathrm{H}_{2}$ production is excreted by the lungs, and rates of breath $\mathrm{H}_{2}$ excretion and production correlates well ${ }^{(85)}$. Smoking raises and exercise lowers $\mathrm{H}_{2}$ concentrations and is therefore not allowed during these tests ${ }^{(85)}$.

Orocaecal transit time is increased in subjects with alcoholism, but it also appears to be increased among individuals who drink moderate amounts of alcohol as assessed by the $\mathrm{H}_{2}$ breath test ${ }^{(86,87)}$. Clearly, this has the potential to alter the occurrence of specific breath constituents and the overall postprandial breath profile. Alcohol is largely metabolised to acetaldehyde by dehydrogenase enzymes, leading to the appearance of high concentrations of acetaldehyde in the breath after alcohol consumption ${ }^{(88,89)}$. Somatic cells and microbes representing normal human gut flora are also able to produce acetaldehyde from ethanol ${ }^{(90)}$. After the ingestion of alcoholic beverages, there are high local acetaldehyde concentrations in the saliva, gastric juice and the contents of the large intestine. In addition, microbes may produce acetaldehyde endogenously in the absence of exogenous alcohol $\operatorname{administration}^{(90)}$.

Complex carbohydrates and fibre. Complex carbohydrate and fibre increase gut transit time and therefore increase the quantity of fermentable, non-absorbed carbohydrate reaching the distal intestine, and hence increase the production of gut-derived $\mathrm{H}_{2}$ and $\mathrm{CH}_{4}{ }^{\left({ }^{1-93)}\right.}$. In some groups of subjects, there appears to be an adaptation to high intakes of resistant starch over time and an apparent relationship with insulin sensitivity ${ }^{(94)}$. Using breath $\mathrm{H}_{2}$ analysis, Strocchi \& Levitt ${ }^{(95)}$ found that 5-10\% of starch in wheat, potatoes and maize is not absorbed by healthy subjects, while rice starch is nearly completely absorbed. The physiological effects of dietary fibre are not always predictable 
from their physicochemical properties ${ }^{(96)}$. For example, maize fibre has been reported to resist fermentation better than potato fibre and to have a lower digestibility ${ }^{(96)}$. However, both dietary fibres increased faecal output of DM, neutral sugars and water. Orocaecal transit time is increased by potato fibre, and it is reported to reduce postprandial plasma levels of total and esterified cholesterol. In contrast, maize fibre has been reported to lower fasting blood cholesterol concentrations and increase the non-esterified cholesterol ratio. A class of non-digestible but fermentable oligosaccharides, trans-galacto-oligosaccharides, was found to increase the concentration of breath $\mathrm{H}_{2}$ and the $\mathrm{N}$ density of the faeces ${ }^{(97)}$, whilst dietary fibre from maize, cassava and amaranth all increased faecal energy loss. Expired breath $\mathrm{H}_{2}$ was highest for those individuals consuming maize or cassava ${ }^{(98)}$. In critically ill patients receiving jejunal feeding with a semi-elemental diet, fibre supplementation appeared to improve microbiota mass and function, being associated with increased carbohydrate fermentation, measured as breath $\mathrm{H}_{2}$ and $\mathrm{CH}_{4}{ }^{(99)}$.

Protein. The ingestion of a high protein-energy meal is associated with some complex changes in breath compounds; the changes in exhaled acetone, $\mathrm{NH}_{3}$ and ethanol concentrations ${ }^{(26)}$ have been discussed above.

Effects of entire diets. A diet that is chronically energy restricted is associated with longevity, which is probably related to a reduction in oxidant stress ${ }^{(100,101)}$; such a diet is also associated with low breath ethane concentrations, that again may relate to reduced oxidant stress ${ }^{(102)}$.

Kundu et al. have found that the amount of breath acetone in exhaled breath was correlated with the rate of fat loss ${ }^{(103)}$ in subjects on a restricted-energy weight-loss programme.

Using a randomised controlled design of the effects of a diet rich in fruit and vegetables, with or without low-fat dairy products for 8 weeks' duration, Miller et al. ${ }^{(104)}$ found that breath ethane was significantly reduced in patients on both fruit- and vegetable-rich diets, but particularly in subjects on a low-fat dairy diet. The endogenous production of methanol is increased after the consumption of fruit ${ }^{(105)}$, its concentrations increasing by as much as an order of magnitude. This is thought to be due to the degradation of natural pectin (which is esterified with methyl alcohol) in the colon. In vivo studies showed that pectin in either a pure form (10 to $15 \mathrm{~g}$ ) or a natural form (in $1 \mathrm{~kg}$ of apples) induces a significant increase of methanol in the breath (and by inference in the blood) of humans ${ }^{(105)}$ to a level similar to that seen following the consumption of alcohol spirits ${ }^{(106)}$.

Effects of pre- and probiotics. In vitro studies of isolated bacterial cultures have demonstrated that the VOC profile that they produce is distinctive, and may be used to differentiate bacterial species ${ }^{(107)}$. Whilst some of these molecules, for example ethanol and acetone, are produced by their human host, other trace gases, for example $\mathrm{H}_{2}$ and indole, are only produced in detectable quantities by bacteria ${ }^{(107)}$. Furthermore, the gases emitted by bacteria also appear to be dependent on the strain of the bacterial isolate $^{(108)}$ and culture conditions ${ }^{(109)}$. Bartram et al..$^{(110)}$ have reported that daily yogurt enriched with Bifidobacterium longum and $5 \mathrm{~g}$ lactulose/l increased breath $\mathrm{H}_{2}$ exhalation and mouth-to-caecum transit time.

SCFA are produced by bacterial fermentation of carbohydrates in the colon, influence gastrointestinal motility ${ }^{(111)}$, and can affect motility at a distance from their site of production. The mechanisms of action of SCFA on gastrointestinal motility have not been completely elucidated. They may involve systemic humoral and neural pathways as well as local reflexes and myogenic responses.

Cellobiose has a $\beta-1,4$ linkage, so it is resistant to hydrolysis by human small-intestinal disaccharidase and, hence, reaches the colon undigested. The excretion of breath $\mathrm{H}_{2}$ gas after cellobiose ingestion was found to be significantly greater than after glucose ingestion ${ }^{(112)}$. In another study, prebiotic treatment increased breath $\mathrm{H}_{2}$ excretion by 3 -fold and reduced hunger ${ }^{(113)}$. The AUC for plasma glucagon-like peptide 1 and the volatile release curve for breath- $\mathrm{H}_{2}$ excretion measured after the meal were significantly correlated with each other ${ }^{(113)}$.

Dietary micronutrients. Micronutrients have the potential to affect redox status and prevailing inflammation, or they may have direct effects on constituents within breath. Furthermore, lung function (forced expiratory volume) appears to be related to dietary vitamin $C^{(114)}$ and fruit intake ${ }^{(115)}$, although the latter study was in children and so the findings may not be the same for adults. Increased concentrations of breath alkanes are associated with reduced antioxidant micronutrient status ${ }^{(45)}$. Supplementation with a cocktail of antioxidant vitamins (vitamin $\mathrm{C}$, vitamin $\mathrm{E}$ and $\beta$-carotene) has been reported to be associated with reduced breath pentane in smokers ${ }^{(116)}$. In contrast, Fe supplements have been found to increase breath ethane concentrations in young women ${ }^{(117)}$. The amount of breath dimethyl selenide has been reported to increase after the ingestion of Se supplements ${ }^{(118)}$ and substantial amounts are found in the breath of individuals with Se toxicity ${ }^{(119)}$, and this may account for the characteristic breath odour in individuals with this condition ${ }^{(119)}$.

\section{Principles of measurement}

The ability to accurately measure concentrations of trace gases in humid breath has only been possible in the last 20-30 years. GC-MS has been used widely used for breath analysis and continues to be vigorously exploited to great effect for this purpose. In GC-MS, breath samples are collected and volatile compounds extracted and pre-concentrated before offline analysis. Whilst GC-MS has allowed the identification of compounds in breath it is not possible to use this technique in real time ${ }^{(3,4)}$. It is disturbed by the large amount of water vapour present in humid exhaled breath. 
Table 2. Summary of methods used for breath analysis

\begin{tabular}{|c|c|c|}
\hline Method & Principle & References \\
\hline GC & $\begin{array}{l}\text { Sample injected onto a chromatographic column using an inert gaseous } \\
\text { mobile phase. The column may be polar or non-polar. The separated } \\
\text { compounds are then detected by MS, flame ionisation or ion mobility } \\
\text { spectrometry }\end{array}$ & Phillips $^{(3)}$, Sanchez \& Sachs ${ }^{(153)}$ \\
\hline PTR-MS and PTR-TOF & $\begin{array}{l}\text { VOC are ionised by their reaction with } \mathrm{H}_{3} \mathrm{O}^{+} \text {. Can be performed without } \\
\text { pre-concentration, and can be undertaken online. Compounds identified } \\
\text { by mass:charge ratio of characteristic ions, isomers cannot be differentiated } \\
\text { by PTR-MS and therefore may require further characterisation. Recent } \\
\text { PTR-TOF methods have substantially improved mass resolution and are } \\
\text { sensitive down to parts per trillion }\end{array}$ & $\begin{array}{l}\text { Moser et al. } .^{(125)} \text {, Lirk et al. }{ }^{(126)} \text {, Blake } \\
\text { et al. } .^{(128)} \text {, Herbig et al. }{ }^{(129)}\end{array}$ \\
\hline SIFT-MS & 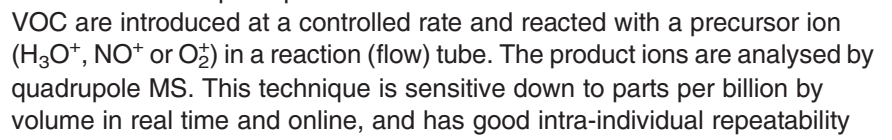 & $\begin{array}{l}\text { Smith \& Španěl }{ }^{(120,155,156)} \text {, Wang }{ }^{(131)} \text {, } \\
\text { Smith et al. }{ }^{(11,154)} \text {, Boshier et al. } .^{(157)}\end{array}$ \\
\hline $\begin{array}{l}\text { Chemical sensors } \\
\text { (noses) }\end{array}$ & $\begin{array}{l}\text { This method relies on the use of chemical sensors, often arranged as arrays, } \\
\text { and linked to a data analysis system for chemical fingerprint analysis with } \\
\text { reference to a database }\end{array}$ & Thaler et al. ${ }^{(134)}$, Oh et al..$^{(158)}$ \\
\hline Chemiluminescence & $\begin{array}{l}\text { This can be used if the trace gas reacts with ozone to generate a } \\
\text { chemiluminescence signal which can be measured using a } \\
\text { photomultiplier tube }\end{array}$ & Toda \& Dasgupta ${ }^{(136)}$ \\
\hline $\begin{array}{l}\text { Optical and laser } \\
\text { spectroscopy }\end{array}$ & $\begin{array}{l}\text { Absorbance spectroscopy of the trace gas is assessed using a laser light } \\
\text { source in the mid-IR range. Recent improvements in the technique have } \\
\text { allowed it to be applied to the real-time measurement of a number of } \\
\text { potentially important trace gases including } \mathrm{NH}_{3} \text {, ethane and NO }\end{array}$ & $\begin{array}{l}\text { Wang \& Sahay }{ }^{(121)}, \text { McCurdy et al. } .^{(122)} \text {, } \\
\text { Lewicki et al. }{ }^{(159)} \text {, Dahnke et al. } .^{(160)}\end{array}$ \\
\hline
\end{tabular}

PTR, proton transfer reaction; TOF, time of flight; VOC, volatile organic compounds; SIFT, selected ion flow tube.

More recent analytical advances include SIFT-MS, proton transfer reaction (PTR)-MS and various optical spectroscopic or electronic 'nose' devices; these are techniques that have allowed real-time analysis of breath ${ }^{(120-123)}$. Spectroscopic detection methods have been designed to detect specific simple molecules of permanent gases, such as $\mathrm{NO}$ and ethane ${ }^{(121)}$ rather than a profile of VOC in breath, but are amenable to real-time applications. The physicochemical principle of electronic nose devices is that exposure of the detector to specific compounds is associated with a change in surface conductivity of the sensor; however, interpretation may be complicated for humid samples ${ }^{(123)}$ and they generally lack positive identification.

\section{Methods commonly used for breath analysis}

Those methods used for breath analysis mentioned above are briefly described below and summarised in Table 2 . The most widely reported breath analytes are shown in Table 3, together with the methods used to detect them, their concentrations, sources and potential confounding factors.

\section{Ion mobility spectrometry}

The aim of ion mobility spectrometry is to identify trace gases by the mobility of their characteristic gas-phase ions or their derivatives in a buffer/carrier gas ${ }^{(124)}$. These ions are produced by exposing the carrier gas/trace gas to a radioactive source or electrical discharge when chemical ionisation reactions result in the analytical drifting ions. The movement of these ions is dependent on their mass and molecular geometry, and their dwell times are used to characterise the original mixture of trace gases. Whilst this approach is not recommended for the identification of unknown compounds, it has been used to determine differences in breath metabolite profiles associated with specific diseases ${ }^{(123)}$.

\section{Proton transfer reaction-MS and proton transfer reaction-time of flight}

In these techniques, precursor hydronium ions $\left(\mathrm{H}_{3} \mathrm{O}^{+}\right)$are injected into the buffer gas, which is usually the gas sample to be analysed, and react with the trace gas present in the sample. The precursor ions react with the trace gas species, producing characteristic ion products that are detected and quantified using a down-stream analytical MS. PTR-MS is sensitive down to and below $\mathrm{ppbv}^{(125-127)}$. The precursor molecules react with most trace gas molecules to produce a protonated molecule $\left(\mathrm{MH}^{+}\right)$. However, the latter nascent ion may be unstable for some compounds, for example, when $\mathrm{M}$ is an alcohol. Furthermore, when the carrier gas in PTR-MS is humid breath, this leads to the formation of cluster ions, for example $\mathrm{H}_{3} \mathrm{O}^{+} \cdot\left(\mathrm{H}_{2} \mathrm{O}\right)_{1,2,3}$ that may make quantitative analysis more complex, although this cluster ion formation is inhibited by the presence of the axial electric field along the flow tube ${ }^{(128)}$. In PTR-time-of-flight analysis, ions are accelerated to uniform energy by an electric field, and subsequently traverse a defined distance. The time of flight of the ion is directly related to the ion's mass:charge ratio, and this allows a mass resolution that is substantially better than for conventional PTR-MS ${ }^{(129)}$. Whilst the original instruments relied on long integration times to attain sufficient sensitivity, recently developed PTR-time of flight instrumentation has improved sensitivity ${ }^{(130)}$, with integration times of $1 \mathrm{~s}$ and a corresponding limit of detection approaching 100 parts per trillion for most compounds, allowing online breath analysis ${ }^{(129)}$. 
Table 3. Summary of breath analytes with reported ranges and sources

\begin{tabular}{|c|c|c|c|c|c|c|}
\hline Compound & Study & Number of subjects & Method & Concentration (ppbv) & Source & Comments \\
\hline \multirow[t]{3}{*}{ Acetaldehyde } & Diskin et al. ${ }^{(22)}$ & 5 & SIFT-MS & Range $2-5$ & Ethanol metabolism ${ }^{(90)}$ & $\begin{array}{l}\text { Oral microbes } \\
\text { Liver }\end{array}$ \\
\hline & Fuchs et al..$^{(161)}$ & $\begin{array}{l}12 \text { lung cancer } \\
\text { patients } \\
12 \text { smokers } \\
12 \text { healthy } \\
\text { volunteers }\end{array}$ & GC-MS & $\begin{array}{l}\text { Lung cancer: } \\
\text { mean }>200\end{array}$ & $\begin{array}{l}\text { Carbohydrate metabolism, } \\
\text { ambient air }\end{array}$ & $\begin{array}{l}\text { No significant difference in } \\
\text { exhaled acetaldehyde concentrations } \\
\text { in all subject groups }\end{array}$ \\
\hline & Turner et al. ${ }^{(27)}$ & 30 & SIFT-MS & $\begin{array}{l}\text { Mean } 24 \text { (range 0- } \\
\text { 104) }\end{array}$ & Ethanol metabolism & $\begin{array}{l}\text { Increased levels detected with } \\
\text { consumption of sweet drinks/food } \\
2 \mathrm{~h} \text { before }\end{array}$ \\
\hline \multirow[t]{2}{*}{ Acetone } & Turner et al. ${ }^{(24)}$ & 30 & $\begin{array}{l}\text { SIFT-MS } \\
\mathrm{H}_{3} \mathrm{O}+\mathrm{O}_{2}^{+}\end{array}$ & $\begin{array}{l}\text { Mean } 477 \text { (range 148- } \\
\text { 2744) }\end{array}$ & $\begin{array}{l}\text { Decarboxylation of } \\
\text { acetoacetate, dehydrogenation } \\
\text { of isopropanol }\end{array}$ & $\begin{array}{l}\text { Levels strongly influenced by physiological } \\
\text { factors other than diet }\end{array}$ \\
\hline & Smith et al. ${ }^{(26)}$ & 6 & SIFT-MS & $\begin{array}{l}\text { Pre-meal: range } 200- \\
600 \\
5 \text { h Post-meal: mean } \\
\text { about } 200\end{array}$ & $\begin{array}{l}\text { Related to blood glucose in } \\
\text { some studies }{ }^{(162)}\end{array}$ & \\
\hline \multirow[t]{4}{*}{$\mathrm{NH}_{3}$} & Diskin et al. ${ }^{(22)}$ & 5 & $\begin{array}{l}\text { SIFT-MS } \\
\mathrm{H}_{3} \mathrm{O}+\mathrm{O}_{2}^{+}\end{array}$ & Range 422-2389 & Protein metabolism ${ }^{(163)}$ & $\begin{array}{l}\text { Not much day-to-day variation in } \\
\text { individuals }\end{array}$ \\
\hline & Turner et al. ${ }^{(24)}$ & 30 & SIFT-MS & $\begin{array}{l}\text { Mean } 833 \text { (range 248- } \\
\text { 2935) }\end{array}$ & Protein metabolism & $\begin{array}{l}\text { Breath concentrations influenced by age } \\
\text { and background air }\end{array}$ \\
\hline & $\begin{array}{l}\text { Španěl } \\
\text { et al. }\end{array}$ & 6 & SIFT-MS & Range 200-1750 & & Protein diet \\
\hline & Smith et al. ${ }^{(26)}$ & 6 & SIFT-MS & $\begin{array}{l}\text { Pre-meal: range } 300- \\
600 \\
5 \mathrm{~h} \text { Post-meal: range } \\
600-1800\end{array}$ & & \\
\hline Allyl sulfides & Rosen et al. ${ }^{(164)}$ & Simulated & Thermal desorption GC-MS & & Garlic $^{(165,166)}$ & $\begin{array}{l}\text { Allicin decomposes in gastric acid leading } \\
\text { to the formation of allyl sulfides }{ }^{(167)}\end{array}$ \\
\hline \multirow{2}{*}{$\begin{array}{l}\text { Carbon } \\
\text { disulfide }\end{array}$} & Phillips $^{(168)}$ & 42 & GC-MS & Range $0.005-0.008$ & Atmospheric $^{(168)}$ & \\
\hline & $\begin{array}{l}\text { Ciaffoni } \\
\text { et al. }\end{array}$ & & Laser absorption spectroscopy & & Gut bacteria $^{(170)}$ & \\
\hline \multirow[t]{2}{*}{$\begin{array}{l}\text { Carbonyl } \\
\text { sulfide }\end{array}$} & $\begin{array}{l}\text { Wysocki } \\
\text { et al. }\end{array}$ & Simulated & $\begin{array}{l}\text { Pulsed quantum cascade-based } \\
\text { sensor }\end{array}$ & & Gut bacteria ${ }^{(170)}$ & \\
\hline & $\begin{array}{l}\text { Halmer } \\
\text { et al. }{ }^{(172)}\end{array}$ & Simulated & Mid-cavity leak out spectroscopy & & & \\
\hline \multirow[t]{3}{*}{$\mathrm{CO}$} & $\begin{array}{l}\text { Middleton \& } \\
\text { Morice }^{(173)}\end{array}$ & 65 & Electronic nose device & $\begin{array}{l}\text { Non-smokers: mean } \\
1830 \\
\text { Smokers: mean } 17400\end{array}$ & Haem catabolism ${ }^{(174)}$ & $\begin{array}{l}\text { Formation catalysed by hame } \\
\text { oxygenase }^{(175)} \text { and CO production is } \\
\text { increased by haemolysis }^{(174)}\end{array}$ \\
\hline & Paredi et al. ${ }^{(176)}$ & 37 & Electrochemical & $\begin{array}{l}\text { Non-diabetics: mean } \\
2900 \\
\text { Diabetics: range } \\
\text { 4-5000 }\end{array}$ & & \\
\hline & $\begin{array}{l}\text { Costello } \\
\text { et al. }{ }^{(177)}\end{array}$ & 10 & Electrochemical detector & $\begin{array}{l}\text { Non-smokers: } \\
\text { mean 2100 } \\
\text { (range 600-4900) } \\
\text { Smokers: mean 12800 } \\
\text { (range 8300-18700) }\end{array}$ & & \\
\hline
\end{tabular}




\begin{tabular}{|c|c|c|c|c|c|c|}
\hline \multirow[t]{2}{*}{$\begin{array}{l}\text { Dimethyl } \\
\text { sulfide }\end{array}$} & \multicolumn{2}{|l|}{$\begin{array}{l}\text { Tangerman } \\
\text { et al. }{ }^{(178)}\end{array}$} & $\mathrm{GC}$ & $\begin{array}{l}\text { Normal: mean } 7.6 \\
\text { (sD 0.6) } \\
\text { Cirrhotics: mean } 41 \\
\text { (SD 11.5) }\end{array}$ & \multirow[t]{2}{*}{ Methionine metabolism } & \multirow[t]{2}{*}{$\begin{array}{l}\text { Production is dependent on intestinal } \\
\text { bacteria }^{(170)}\end{array}$} \\
\hline & Azad et al..$^{(179)}$ & Simulated & Chemiluminescence & & & \\
\hline Ethane & Paredi et al..$^{(180)}$ & 22 & $\mathrm{GC}$ & Mean 0.88 & Lipid peroxidation ${ }^{(46,48,50)}$ & $\begin{array}{l}\text { The production of ethane and pentane is } \\
\text { dependent on antioxidant status } \\
(181,182)\end{array}$ \\
\hline \multirow[t]{2}{*}{ Ethanol } & Diskin et al..$^{(22)}$ & 5 & $\begin{array}{l}\text { SIFT-MS } \\
\mathrm{H}_{3} \mathrm{O}^{+}\end{array}$ & $\begin{array}{l}\text { Mean } 196 \\
\text { (range 0-474) }\end{array}$ & Gut flora & \\
\hline & Smith et al. ${ }^{(26)}$ & 6 & SIFT-MS & Range $55-121$ & & \\
\hline Ethylene & $\begin{array}{l}\text { Dumitras } \\
\text { et al. } .^{(183)}\end{array}$ & $\begin{array}{l}1 \text { non-smoker } \\
1 \text { smoker }\end{array}$ & Photo-acoustic spectroscopy & Mean 20 & Lipid peroxidation ${ }^{(46,48-50)}$ & \\
\hline \multirow[t]{2}{*}{$\mathrm{H}_{2}$} & $\begin{array}{l}\text { Perman } \\
\text { et al. }{ }^{(184)}\end{array}$ & $\begin{array}{l}221 \text { children } \\
9 \text { adults }\end{array}$ & $\mathrm{GC}$ with electrochemical detection & Mean 7100 & Carbohydrate metabolism ${ }^{(81,85)}$ & $\begin{array}{l}\text { Formed by hydrolytic and saccharolytic } \\
\text { bacteria }^{(185)}\end{array}$ \\
\hline & $\begin{array}{l}\text { Costello } \\
\text { et al. }\end{array}$ & 10 & Electrochemical detector & $\begin{array}{l}\text { Mean } 9100 \text { (range } \\
300-34000)\end{array}$ & & Large within-individual variation \\
\hline \multirow[t]{3}{*}{$\begin{array}{l}\text { Hydrogen } \\
\text { cyanide }\end{array}$} & $\begin{array}{l}\text { Schmidt } \\
\text { et al. }\end{array}$ & 19 & Cavity ring down spectroscopy & Range $1.3-6.5$ & $\begin{array}{l}\text { Oxidation of thiocyanate by } \\
\text { peroxidase }^{(186)}\end{array}$ & \\
\hline & $\begin{array}{l}\text { Španěl } \\
\text { et al. }\end{array}$ & 26 & SIFT-MS & Mean 8 & & \\
\hline & $\begin{array}{l}\text { Enderby } \\
\text { et } \text { al. }^{(188)}\end{array}$ & $\begin{array}{l}16 \text { children with } \\
\text { cystic fibrosis } \\
21 \text { children with } \\
\text { asthma }\end{array}$ & SIFT-MS & $\begin{array}{l}\text { Mean } 13.5 \\
\text { Mean } 2 \cdot 0\end{array}$ & $\begin{array}{l}\text { Derived from Pseudomonas } \\
\text { aeruginosa }^{(188)}\end{array}$ & \\
\hline $\begin{array}{l}\text { Hydrogen } \\
\text { sulfide }\end{array}$ & $\begin{array}{l}\text { Costello } \\
\text { et al. }{ }^{(177)}\end{array}$ & 10 & Electrochemical detector & $\begin{array}{l}\text { Mean } 330 \text { (range } \\
0-1300 \text { ) }\end{array}$ & Oral flora & \\
\hline \multirow[t]{5}{*}{ Isoprene } & $\begin{array}{l}\text { Turner } \\
\text { et al. } .^{(23,30)}\end{array}$ & 20 & $\begin{array}{l}\text { SIFT-MS } \\
\mathrm{NO}^{+}\end{array}$ & $\begin{array}{l}\text { Mean } 118 \text { (range } \\
0-474)\end{array}$ & Cholesterol metabolism ${ }^{(189,190)}$ & $\begin{array}{l}\text { Exercise }^{(190)} \\
\text { Age } \\
\text { Haemodialysis } \\
\text { Statin therapy }^{(191)}\end{array}$ \\
\hline & Jones et al. ${ }^{(192)}$ & 16 & $\begin{array}{l}\text { Thermal desorption GC and diode } \\
\text { array UV detection }\end{array}$ & Range 36-231 & Cholesterol metabolism ${ }^{(189,190)}$ & $\begin{array}{l}\text { No statistical difference in isoprene } \\
\text { concentrations between men and women }\end{array}$ \\
\hline & Smith et al. ${ }^{(25)}$ & 200 & SIFT-MS & Range 28-54 & & Age dependent \\
\hline & $\begin{array}{l}\text { Davies } \\
\text { et al. } .^{(193)}\end{array}$ & 19 & SIFT-MS & Mean 89 (sD 36) & & \\
\hline & $\begin{array}{l}\text { Taucher } \\
\text { et al. }{ }^{(194)}\end{array}$ & & PTR-MS & Range $100-1000$ & & $\begin{array}{l}\text { Children }<6 \text { years had values less than } \\
\text { adults }\end{array}$ \\
\hline Methane & $\begin{array}{l}\text { Dryahina } \\
\text { et al. }\end{array}$ & 75 & $\begin{array}{l}\text { SIFT-MS } \\
\mathrm{O}_{2}^{+}\end{array}$ & Range 6-30 & $\begin{array}{l}\text { Carbohydrate metabolism }{ }^{(196-} \\
\text { 198) }\end{array}$ & $\begin{array}{l}\text { Most produced by Methanobrevibacter } \\
\text { smithii which uses } \mathrm{H}_{2} \text { to reduce } \mathrm{CO}_{2}{ }^{(199)}\end{array}$ \\
\hline \multirow[t]{2}{*}{ Methanol } & Turner et al. ${ }^{(23)}$ & 30 & $\begin{array}{l}\text { SIFT-MS } \\
\mathrm{H}_{3} \mathrm{O}^{+}\end{array}$ & $\begin{array}{l}\text { Median } 461 \text { (range 32- } \\
\text { 1684) }\end{array}$ & Fruit metabolism ${ }^{(105)}$ & $\begin{array}{l}\text { Inversely related to BMI } \\
\text { Fruit and alcohol }\end{array}$ \\
\hline & $\begin{array}{l}\text { Taucher } \\
\text { et al. }{ }^{(106)}\end{array}$ & & PTR-MS & Mean 400 & & \\
\hline Methylamine & $\begin{array}{l}\text { Marinov } \\
\text { et al. }\end{array}$ & Simulated & $\begin{array}{l}\text { Near-IR laser spectrometer based } \\
\text { on the cavity ring down detection }\end{array}$ & & Protein metabolism & \\
\hline Methyl nitrate & Novak et al. ${ }^{(201)}$ & $\begin{array}{l}10 \text { T1DM } \\
\text { children }\end{array}$ & $\begin{array}{l}\text { GC offline using electron } \\
\text { capture }^{(201)}\end{array}$ & Range $0.005-0.010$ & Oxidative processes & Correlation with blood glucose \\
\hline $\begin{array}{l}\text { Methyl } \\
\text { mercaptan }\end{array}$ & Chen et al. ${ }^{(170)}$ & & & & Methionine metabolism ${ }^{(170)}$ & \\
\hline NO & $\begin{array}{l}\text { Paredi } \\
\text { et al. }{ }^{(202,203)}\end{array}$ & & $\begin{array}{l}\text { Chemiluminescence, following its } \\
\text { reaction with } \mathrm{O}_{3}^{(204)}\end{array}$ & Mean 6.7 & $\begin{array}{l}\text { NO synthase and } \\
\text { arginine }^{(205-208)}\end{array}$ & $\begin{array}{l}\text { Concentration is dependent on } \\
\text { exhalation flow rate } \text { rag) }^{(209)}\end{array}$ \\
\hline
\end{tabular}




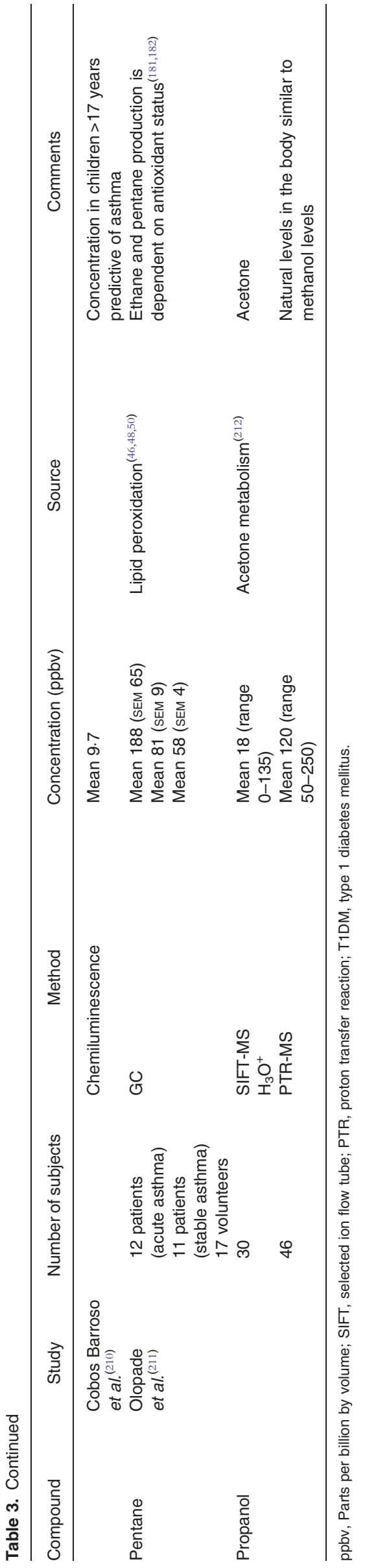

\section{Selected ion flow tube-MS}

SIFT-MS combines the fast flow tube technique, chemical ionisation using selected precursor ions, either $\mathrm{H}_{3} \mathrm{O}^{+}, \mathrm{NO}^{+}$or $\mathrm{O}_{2}^{+}$, and quantitative MS that allows online, real-time quantitative analysis of the trace gases (such as ethanol, acetaldehyde, $\mathrm{NH}_{3}$, acetone and isoprene, etc.) in single breath exhalations down to concentrations in the ppbv range in a timescale of seconds ${ }^{(131)}$. SIFT-MS relies on chemical ionisation by the chosen precursor ions of the trace gas molecules in air/breath samples introduced into He carrier gas. These reactions proceed for an accurately defined time, the precursor and product ions being detected and counted by a downstream quadrupole mass spectrometer, thus effecting quantification. Because the absolute concentrations of trace gases in single breath exhalation can be determined by SIFT-MS down to ppbv concentrations, this obviates the need for offline sample collection for the most common breath trace gases. A numerical algorithm allows the calculation, in real time, of absolute concentrations of trace gases, including VOC and water vapour ${ }^{(132)}$.

\section{Optical and laser spectroscopic detection}

Laser spectroscopic detection techniques have high sensitivity and high selectivity, but also have the advantageous features of near real-time response and low instrument cost. Of approximately thirty-five biomarkers quantified using this method, fourteen species have been analysed in exhaled human breath by high-sensitivity laser spectroscopic techniques, for example acetone, $\mathrm{NH}_{3}, \mathrm{CO}_{2}$, ethane, $\mathrm{CH}_{4}$ and $\mathrm{NO}$. The spectral fingerprints of these potentially useful biomarkers span from the UV to the mid-IR spectral regions and the detection limits achieved by the laser techniques range from parts per million by volume to ppbv. Sensors using the laser spectroscopic techniques are already commercially available for a few breath biomarkers, for example $\mathrm{CO}_{2}$ and $\mathrm{NO}^{(121)}$.

\section{Electronic nose detection}

Electronic noses, or artificial sensors of volatiles including odorants, have been developed over the last 10 years to perform a variety of identification tasks in various industries. Electronic noses produce a chemical fingerprint of the sample, and this is matched to a reference database ${ }^{(133)}$. This powerful technology is only beginning to be introduced in the field of medicine, but is promising in its potential to assist in diagnosis ${ }^{(134)}$.

\section{Chemiluminescence}

Chemiluminescence (CL) is a powerful analytical tool in trace gas analysis. CL monitoring has been used as universal nitrogen and sulfur detectors for GC and capillary electrophoresis $^{(135)}$. CL detection can be used as the basis of compact and sensitive analysers for real-sample analysis. Isoprene and sulfur compounds in expired breath and atmospheric samples have been successfully measured by coupling to a small collection system. Short-term adsorbent collection enhances the sensitivity and considerably reduces interference. The organosulfur 
compounds methyl mercaptan and dimethyl sulfide can be separated on the same column that is used for collection ${ }^{(136)}$.

\section{Conclusions}

Breath analysis is becoming more accessible for clinical and physiological applications. Expired breath is a complex mixture of low-molecular-weight volatile compounds that are derived from diet and endogenous metabolism, or from micro-organisms in the gastrointestinal and respiratory tracts. Metabolic, inflammatory and neoplastic conditions are reported to be associated with characteristic breath profiles, and breath analysis has been promoted as a potentially simple, non-invasive method for screening and monitoring conditions such as asthma, diabetes mellitus and lung cancer. However, there are a number of factors that affect the concentrations of compounds in breath, including diet, physical activity and smoking habit, and it will be important to better understand how these factors influence breath composition as the applications of breath analysis broaden in scope. In order to apply breath analysis to investigations of human nutrition, it would be important to consider any concomitant co-morbidity, including renal and liver dysfunction, neoplastic disease, infection and inflammation. Breath sampling should probably take place under standardised conditions, for example after an overnight fast, and involve diurnal and longitudinal monitoring. A method should be used that is less sensitive to the local release of compounds from the oral cavity. Whichever methods are used should probably also have defined age-related reference ranges.

\section{Acknowledgements}

The North Staffordshire Medical Institute provided a grant to G. A. A. F., P. S. and D. S., but had no role in the writing of the review.

All the authors were involved in the drafting and revision of the manuscript.

P. Š. and D. S. are shareholders and directors of Trans Spectra Limited, UK.

\section{References}

1. Pauling L, Robinson AB, Teranish R, et al. (1971) Quantitative analysis of urine vapor and breath by gas-liquid partition chromatography. Proc Natl Acad Sci U S A 68, 2374-2376.

2. Risby T \& Solga $S$ (2006) Current status of clinical breath analysis. Appl Phys B 85, 421-426.

3. Phillips M (1997) Method for the collection and assay of volatile organic compounds in breath. Anal Biochem 247, 272-278.

4. Phillips M, Herrera J, Krishnan S, et al. (1999) Variation in volatile organic compounds in the breath of normal humans. J Chromatogr B Biomed Sci Appl 729, 75-88.

5. Španěl P \& Smith D (2011) Volatile compounds in health and disease. Curr Opin Clin Nutr Metab Care 14, 455-460.

6. Teraishi T, Ozeki Y, Hori H, et al. (2012) C-13-phenylalanine breath test detects altered phenylalanine kinetics in schizophrenia patients. Transl Psycbiatry 2, e119.

7. Louhelainen N, Myllarniemi M, Rahman I, et al. (2008) Airway biomarkers of the oxidant burden in asthma and chronic obstructive pulmonary disease: current and future perspectives. Int J Chron Obstruct Pulmon Dis 3, 585-603.

8. Salerno-Kennedy R \& Cashman KD (2005) Potential applications of breath isoprene as a biomarker in modern medicine: a concise overview. Wien Klin Wochenschr 117, 180-186.

9. Hamer HM, De Preter V, Windey K, et al. (2012) Functional analysis of colonic bacterial metabolism: relevant to health? $A m$ J Physiol Gastrointest Liver Physiol 302, G1-G9.

10. Popov TA (2011) Human exhaled breath analysis. Ann Allergy Asthma Immunol 106, 451-456.

11. Smith D, Turner C \& Španěl P (2007) Volatile metabolites in the exhaled breath of healthy volunteers: their levels and distributions. $J$ Breath Res 1, 014004.

12. Zhang Z \& Li G (2010) A review of advances and new developments in the analysis of biological volatile organic compounds. Microchem J 95, 127-139.

13. Singh S \& Evans TW (1997) Nitric oxide, the biological mediator of the decade: fact or fiction? Eur Respir J 10, 699-707.

14. Weinberg JB (1998) Nitric oxide production and nitric oxide synthase type 2 expression by human mononuclear phagocytes: a review. Mol Med 4, 557-591.

15. Wang T, Pysanenko A, Dryahina K, et al. (2008) Analysis of breath, exhaled via the mouth and nose, and the air in the oral cavity. J Breath Res 2, 037013.

16. Smith D, Wang T, Pysanenko A, et al. (2008) A selected ion flow tube mass spectrometry study of ammonia in mouth- and nose-exhaled breath and in the oral cavity. Rapid Commun Mass Spectrom 22, 783-789.

17. van den Broek AM, Feenstra L \& de Baat C (2007) A review of the current literature on aetiology and measurement methods of halitosis. J Dent 35, 627-635.

18. Španěl P, Turner C, Wang TS, et al. (2006) Generation of volatile compounds on mouth exposure to urea and sucrose: implications for exhaled breath analysis. Physiol Meas 27, N7-N17.

19. Hodgson M, Linforth RST \& Taylor AJ (2003) Simultaneous realtime measurements of mastication, swallowing, nasal airflow, and aroma release. J Agric Food Chem 51, 5052-5057.

20. Herbig J, Titzmann T, Beauchamp J, et al. (2008) Buffered endtidal (BET) sampling - a novel method for real-time breath-gas analysis. J Breath Res 2, 037008

21. Birken T, Schubert J, Miekisch W, et al. (2006) A novel visually $\mathrm{CO}_{2}$ controlled alveolar breath sampling technique. Technol Health Care 14, 499-506.

22. Diskin AM, Španěl P \& Smith D (2003) Time variation of ammonia, acetone, isoprene and ethanol in breath: a quantitative SIFT-MS study over 30 days. Physiol Meas 24, 107-119.

23. Turner C, Španěl P \& Smith D (2006) A longitudinal study of methanol in the exhaled breath of 30 healthy volunteers using selected ion flow tube mass spectrometry, SIFT-MS. Physiol Meas 27, 637-648.

24. Turner C, Španěl P \& Smith D (2006) A longitudinal study of ammonia, acetone and propanol in the exhaled breath of 30 subjects using selected ion flow tube mass spectrometry, SIFT-MS Physiol Meas 27, 321-337.

25. Smith D, Španěl P, Enderby B, et al. (2010) Isoprene levels in the exhaled breath of 200 healthy pupils within the age range 7-18 years studied using SIFT-MS. J Breath Res 4, 017101.

26. Smith D, Španěl P \& Davies S (1999) Trace gases in breath of healthy volunteers when fasting and after a protein-calorie meal: a preliminary study. J Appl Physiol 87, 1584-1588.

27. Turner C, Španěl P \& Smith D (2006) A longitudinal study of ethanol and acetaldehyde in the exhaled breath of healthy volunteers using selected-ion flow-tube mass spectrometry. Rapid Commun Mass Spectrom 20, 61-68.

28. Schmidt F, Metsala M, Vaittinen O, et al. (2011) Background levels and diurnal variations of hydrogen cyanide in breath and emitted from skin. J Breath Res 5, 046004.

29. King J, Mochalski P, Kupferthaler A, et al. (2010) Dynamic profiles of volatile organic compounds in exhaled breath as 
determined by a coupled PTR-MS/GC-MS study. Physiol Meas 31, 1169-1184.

30. Turner C, Španěl P \& Smith D (2006) A longitudinal study of breath isoprene in healthy volunteers using selected ion flow tube mass spectrometry (SIFT-MS). Physiol Meas 27, 13-22.

31. King J, Koc H, Unterkofler K, et al. (2010) Physiological modeling of isoprene dynamics in exhaled breath. J Theor Biol 267, 626-637.

32. St Croix CM, Wetter TJ, Pegelow DF, et al. (1999) Assessment of nitric oxide formation during exercise. Am J Respir Crit Care Med 159, 1125-1133.

33. Dummer JF, Storer MK, Hu WP, et al. (2010) Accurate, reproducible measurement of acetone concentration in breath using selected ion flow tube-mass spectrometry. J Breath Res 4, 046001.

34. Beauchamp J, Kirsch F \& Buettner A (2010) Real-time breath gas analysis for pharmacokinetics: monitoring exhaled breath by on-line proton-transfer-reaction mass spectrometry after ingestion of eucalyptol-containing capsules. J Breath Res 4, 026006.

35. Lodhia P, Yaegaki K, Khakbaznejad A, et al. (2008) Effect of green tea on volatile sulfur compounds in mouth air. J Nutr Sci Vitaminol 54, 89-94.

36. Hodgson MD, Langridge JP, Linforth RST, et al. (2005) Aroma release and delivery following the consumption of beverages. J Agric Food Chem 53, 1700-1706.

37. Buffo RA, Rapp JA, Krick T, et al. (2005) Persistence of aroma compounds in human breath after consuming an aqueous model aroma mixture. Food Chem 89, 103-108.

38. Cheng H (2010) Volatile flavor compounds in yogurt: a review. Crit Rev Food Sci Nutr 50, 938-950.

39. Plaza-Bolanos P, Garrido Frenich A \& Martinez Vidal JL (2010) Polycyclic aromatic hydrocarbons in food and beverages. Analytical methods and trends. J Chromatogr A 1217, 6303-6326.

40. Varlet V \& Fernandez X (2010) Review. Sulfur-containing volatile compounds in seafood: occurrence, odorant properties and mechanisms of formation. Food Sci Technol Int 16, 463-503.

41. Lowe F \& Cemeli E (2011) Biomarkers of oxidative stress and the relationship to cigarette smoking. Mini-Rev Org Chem 8, 377-386.

42. Comandini A, Marzano V, Curradi G, et al. (2010) Markers of anti-oxidant response in tobacco smoke exposed subjects: a datamining review. Pulm Pharmacol Ther 23, 482-492.

43. Filipiak W, Ruzsanyi V, Mochalski P, et al. (2012) Dependence of exhaled breath composition on exogenous factors, smoking habits and exposure to air pollutants. J Breath Res 6, 036008.

44. Yao H \& Rahman I (2011) Experimental models to study cigarette smoke-induced oxidative stress in vitro and in vivo in preclinical models, and in smokers and patients with airways disease. In Studies on Experimental Models: Oxidative Stress in Applied Basic Research and Clinical Practice, pp. 399-420 [S Basu and L Wiklund, editors]. New York: Humana Press.

45. Aghdassi E \& Allard JP (2000) Breath alkanes as a marker of oxidative stress in different clinical conditions. Free Radical Biol Med 28, 880-886.

46. Allerheiligen SRB, Ludden TM \& Burk RF (1987) The pharmacokinetics of pentane, a by-product of lipid-peroxidation. Drug Metab Dispos 15, 794-800.

47. Bernhard D \& Wang X (2007) Smoking, oxidative stress and cardiovascular diseases - do anti-oxidative therapies fail? Curr Med Chem 14, 1703-1712.

48. Horvat RJ, Lane WG, Ng H, et al. (1964) Saturated hydrocarbons from autoxidizing methyl linoleate. Nature 203, 523-524.

49. Lieberman M \& Mapson LW (1964) Genesis and biogenesis ethylene. Nature 204, 343-345.

50. Riely CA, Cohen G \& Lieberma M (1974) Ethane evolution: new index of lipid peroxidation. Science 183, 208-210.

51. Risby TH, Jiang L, Stoll S, et al. (1999) Breath ethane as a marker of reactive oxygen species during manipulation of diet and oxygen tension in rats. J Appl Physiol 86, 617-622.

52. Andreoni KA, Kazui M, Cameron DE, et al. (1999) Ethane: a marker of lipid peroxidation during cardiopulmonary bypass in humans. Free Radical Biol Med 26, 439-445.
53. Kneepkens CMF, Lepage G \& Roy CC (1994) The potential of the hydrocarbon breath test as a measure of lipid-peroxidation. Free Radical Biol Med 17, 127-160.

54. Do BKQ, Garewal HS, Clements NC, et al. (1996) Exhaled ethane and antioxidant vitamin supplements in active smokers. Chest 110 , 159-164.

55. Miller III ER, Appel LJ, Jiang L, et al. (1997) The impact of cigarette smoking on measures of oxidative damage. Circulation 96, 1097-1101.

56. Hoshino E, Shariff R, Vangossum A, et al. (1990) Vitamin E suppresses increased lipid-peroxidation in cigarette smokers. JPEN J Parenter Enteral Nutr 14, 300-305.

57. Allard JP, Royall D, Kurian R, et al. (1994) Effects of $\beta$-carotene supplementation on lipid-peroxidation in humans. Am J Clin Nutr 59, 884-890.

58. Gelmont D, Stein RA \& Mead JF (1981) The bacterial origin of rat breath pentane. Biochem Biophys Res Commun 102, 932-936.

59. Hrdlicka L, Dryahina K, Spanel P, et al. (2012) Tu1248: noninvasive quantification of volatile metabolites in breath: a potential indicator of inflammatory bowel diseases activity. Gastroenterology 142, Suppl., S784.

60. Fritz M, Kasper H \& Siebert G (1983) Exhalation of hydrogen $\left(\mathrm{H}_{2}\right)$ and methane $\left(\mathrm{CH}_{4}\right)$ under various nutritional conditions. Ernahrungs Umschau 30, 232-233.

61. Sohal RS, Ku HH, Agarwal S, et al. (1994) Oxidative damage, mitochondrial oxidant generation and antioxidant defenses during aging and in response to food restriction in the mouse. Mech Ageing Dev 74, 121-133.

62. Schwarz KB, Cox J, Sharma S, et al. (1998) Progressive decrease in plasma omega 3 and omega 6 fatty acids during pregnancy: time course and effects of dietary fats and antioxidant nutrients. J Nutr Environ Med 8, 335-344.

63. Schwarz KB, Cox J, Sharma S, et al. (1995) Cigarette smoking is pro-oxidant in pregnant women regardless of antioxidant nutrient intake. J Nutr Environ Med 5, 225-234.

64. Allard JP, Kurian R, Aghdassi E, et al. (1997) Lipid peroxidation during $n-3$ fatty acid and vitamin $\mathrm{E}$ supplementation in humans. Lipids 32, 535-541.

65. Fooks LJ \& Gibson GR (2002) In vitro investigations of the effect of probiotics and prebiotics on selected human intestinal pathogens. FEMS Microbiol Ecol 39, 67-75.

66. Steer T, Carpenter H, Tuohy K, et al. (2000) Perspectives on the role of the human gut microbiota and its modulation by pro- and prebiotics. Nutr Res Rev 13, 229-254.

67. Musso G, Gambino R \& Cassader M (2011) Interactions between gut microbiota and host metabolism predisposing to obesity and diabetes. Annu Rev Med 62, 361-380.

68. Van Citters GW \& Lin HC (2006) Ileal brake: neuropeptidergic control of intestinal transit. Curr Gastroenterol Rep 8, 367-373.

69. Kontogiorgis C, Bompou E, Ntella M, et al. (2010) Natural products from Mediterranean diet: from anti-inflammatory agents to dietary epigenetic modulators. Anti-Inflam Anti-Allergy Agents Med Chem 9, 101-124.

70. Garcia-Lafuente A, Moro C, Villares A, et al. (2010) Mushrooms as a source of anti-inflammatory agents. Anti-Inflam Anti-Allergy Agents Med Chem 9, 125-141.

71. Garcia-Lafuente A, Guillamon E, Villares A, et al. (2009) Flavonoids as anti-inflammatory agents: implications in cancer and cardiovascular disease. Inflam Res 58, 537-552.

72. Kowaltowski AJ (2011) Caloric restriction and redox state: does this diet increase or decrease oxidant production? Redox Rep 16, 237-241.

73. Bouayed J \& Bohn T (2010) Exogenous antioxidants-doubleedged swords in cellular redox state health beneficial effects at physiologic doses versus deleterious effects at high doses. Oxid Med Cell Longev 3, 228-237.

74. Rosenkranz SK, Townsend DK, Steffens SE, et al. (2010) Effects of a high-fat meal on pulmonary function in healthy subjects. Eur J Appl Physiol 109, 499-506. 
75. Barros R, Moreira A, Fonseca J, et al. (2011) Dietary intake of $\alpha$-linolenic acid and low ratio of n-6:n-3 PUFA are associated with decreased exhaled NO and improved asthma control. $\mathrm{Br} \mathrm{J}$ Nutr 106, 441-150.

76. Kalapos MP (2003) On the mammalian acetone metabolism: from chemistry to clinical implications. Biochim Biophys Acta 1621, 122-139.

77. Musa-Veloso K, Likhodii SS \& Cunnane SC (2002) Breath acetone is a reliable indicator of ketosis in adults consuming ketogenic meals. Am J Clin Nutr 76, 65-70.

78. Španěl P, Dryahina K, Rejskova A, et al. (2011) Breath acetone concentration; biological variability and the influence of diet. Physiol Meas 32, N23-N31.

79. Musa-Veloso K, Rarama E, Comeau F, et al. (2002) Epilepsy and the ketogenic diet: assessment of ketosis in children using breath acetone. Pediatr Res 52, 443-448.

80. Jones A \& Rossner S (2007) False-positive breath-alcohol test after a ketogenic diet. Int J Obes 31, 559-561.

81. Levitt MD (1969) Production and excretion of hydrogen gas in man. N Engl J Med 281, 122-127.

82. Avallone EV, De Carolis A, Loizos P, et al. (2010) Hydrogen breath test - diet and basal $\mathrm{H}_{2}$ excretion: a technical note. Digestion 82, 39-41.

83. Rumessen JJ, Hamberg O \& Gudmandhoyer E (1989) Influence of orocecal transit-time on hydrogen excretion after carbohydrate malabsorption. Gut 30, 811-814.

84. Rumessen JJ, Hamberg O \& Gudmandhoyer E (1990) Interval sampling of end-expiratory hydrogen $\left(\mathrm{H}_{2}\right)$ concentrations to quantify carbohydrate malabsorption by means of lactulose standards. Gut 31, 37-42.

85. Simren M \& Stotzer PO (2006) Use and abuse of hydrogen breath tests. Gut 55, 297-303.

86. Addolorato G, Montalto M, Capristo E, et al. (1997) Influence of alcohol on gastrointestinal motility: lactulose breath hydrogen testing in orocecal transit time in chronic alcoholics, social drinkers and teetotaler subjects. Hepatogastroenterology 44, 1076-1081.

87. Wegener M, Schaffstein J, Dilger U, et al. (1991) Gastrointestinal transit of solid liquid meal in chronic alcoholics. Dig Dis Sci 36, 917-923.

88. Smith D, Wang TS \& Španěl P (2002) On-line, simultaneous quantification of ethanol, some metabolites and water vapour in breath following the ingestion of alcohol. Physiol Meas 23, 477-489.

89. Mitsubayashi K, Matsunaga H, Nishio G, et al. (2005) Bioelectronic sniffers for ethanol and acetaldehyde in breath air after drinking. Biosens Bioelectron 20, 1573-1579.

90. Salaspuro MP (2003) Acetaldehyde, microbes, and cancer of the digestive tract. Crit Rev Clin Lab Sci 40, 183-208.

91. Fritz M, Siebert G \& Kasper H (1985) Dose dependence of breath hydrogen and methane in healthy-volunteers after ingestion of a commercial disaccharide mixture, Palatinit. Br J Nutr 54, 389-400.

92. Fritz M, Kasper H, Schrezenmeir J, et al. (1985) Effect of acarbose on the production of hydrogen and methane and on hormonal parameters in young adults under standardized low-fiber mixed diets. $Z$ Ernabrungswiss 24, 1-18.

93. Madsen JL, Linnet J \& Rumessen JJ (2006) Effect of nonabsorbed amounts of a fructose-sorbitol mixture on small intestinal transit in healthy volunteers. Dig Dis Sci 51, 147-153.

94. Behall KM \& Howe JC (1997) Breath-hydrogen production and amylose content of the diet. Am J Clin Nutr 65, 1783-1789.

95. Strocchi A \& Levitt MD (1991) Measurement of starch absorption in humans. Can J Physiol Pharmacol 69, 108-110.

96. Cherbut C, Aube AC, Mekki N, et al. (1997) Digestive and metabolic effects of potato and maize fibres in human subjects. $\mathrm{Br} \mathrm{J}$ Nutr 77, 33-46.

97. Alles MS, Hartemink R, Meyboom S, et al. (1999) Effect of transgalactooligosaccharides on the composition of the human intestinal microflora and on putative risk markers for colon cancer. $A m \mathrm{~J}$ Clin Nutr 69, 980-991.
98. Hamaker BR, Rivera K, Morales E, et al. (1991) Effect of dietary fiber and starch on fecal composition in preschool children consuming maize, amaranth, or cassava flours. J Pediatr Gastroenterol Nutr 13, 59-66.

99. O'Keefe SJ, Ou J, Delany JP, et al. (2011) Effect of fiber supplementation on the microbiota in critically ill patients. World J Gastrointest Pathophysiol 2, 138-145.

100. Beckman KB \& Ames BN (1998) The free radical theory of aging matures. Physiol Rev 78, 547-581.

101. Trepanowski JF, Canale RE, Marshall KE, et al. (2011) Impact of caloric and dietary restriction regimens on markers of health and longevity in humans and animals: a summary of available findings. Nutr J 10, 107.

102. Habib MP, Dickerson F \& Mooradian AD (1990) Ethane production rate in vivo is reduced with dietary restriction. I Appl Physiol 68, 2588-2590.

103. Kundu SK, Bruzek JA, Nair R, et al. (1993) Breath acetone analyzer: diagnostic tool to monitor dietary fat loss. Clin Chem 39, 87-92.

104. Miller ER, Appel LJ \& Risby TH (1998) Effect of dietary patterns on measures of lipid peroxidation: results from a randomized clinical trial. Circulation 98, 2390-2395.

105. Lindinger W, Taucher J, Jordan A, et al. (1997) Endogenous production of methanol after the consumption of fruit. Alcohol Clin Exp Res 21, 939-943.

106. Taucher J, Lagg A, Hansel A, et al. (1995) Methanol in human breath. Alcohol Clin Exp Res 19, 1147-1150.

107. Zhu J, Bean HD, Kuo YM, et al. (2010) Fast detection of volatile organic compounds from bacterial cultures by secondary electrospray ionization-mass spectrometry. J Clin Microbiol 48, 4426-4431.

108. Shestivska V, Španěl P, Dryahina K, et al. (2012) Variability in the concentrations of volatile metabolites emitted by genotypically different strains of Pseudomonas aeruginosa. J Appl Microbiol 113, 701-713.

109. Chippendale TW, Španěl P \& Smith D (2011) Time-resolved selected ion flow tube mass spectrometric quantification of the volatile compounds generated by E. coli JM109 cultured in two different media. Rapid Commun Mass Spectrom 25, 2163-2172.

110. Bartram HP, Scheppach W, Gerlach S, et al. (1994) Does yogurt enriched with Bifidobacterium longum affect colonic microbiology and fecal metabolites in healthy-subjects? Am J Clin Nutr 59, 428-432.

111. Cherbut C, Aube AC, Blottiere HM, et al. (1997) Effects of shortchain fatty acids on gastrointestinal motility. Scand J Gastroenterol 32, 58-61.

112. Nakamura S, Oku T \& Ichinose A (2004) Bioavailability of cellobiose by tolerance test and breath hydrogen excretion in humans. Nutrition 20, 979-983.

113. Cani PD, Lecourt E, Dewulf EM, et al. (2009) Gut microbiota fermentation of prebiotics increases satietogenic and incretin gut peptide production with consequences for appetite sensation and glucose response after a meal. Am J Clin Nutr $\mathbf{9 0}$, 1236-1243.

114. Britton JR, Pavord ID, Richards KA, et al. (1995) Dietary antioxidant vitamin intake and lung function in the general population. Am J Respir Crit Care Med 151, 1383-1387.

115. Cook DG, Carey IM, Whincup PH, et al. (1997) Effect of fresh fruit consumption on lung function and wheeze in children. Thorax 52, 628-633.

116. Steinberg FM \& Chait A (1998) Antioxidant vitamin supplementation and lipid peroxidation in smokers. Am J Clin Nutr 68, 319-327.

117. Mertz SD, Woodhouse LR, Donangelo CM, et al. (1999) Breath ethane excretion rate in young women is increased by daily iron but not by daily zinc supplementation. FASEB J 13, A241.

118. Kremer D, Ilgen G \& Feldmann J (2005) GC-ICP-MS determination of dimethylselenide in human breath after ingestion of Se-77-enriched selenite: monitoring of in vivo methylation of selenium. Anal Bioanal Chem 383, 509-515.

119. Barceloux DG (1999) Selenium. J Toxicol Clin Toxicol 37, 145-172. 
120. Smith D \& Španěl P (2011) Direct, rapid quantitative analyses of BVOCs using SIFT-MS and PTR-MS obviating sample collection. Trac-Trends Anal Chem 30, 945-959.

121. Wang CJ \& Sahay P (2009) Breath analysis using laser spectroscopic techniques: breath biomarkers, spectral fingerprints, and detection limits. Sensors 9, 8230-8262.

122. McCurdy MR, Bakhirkin Y, Wysocki G, et al. (2007) Recent advances of laser spectroscopy-based techniques for applications in breath analysis. J Breath Res 1, 014001.

123. Smith D \& Španěl P (2007) The challenge of breath analysis for clinical diagnosis and therapeutic monitoring. Analyst 132, 390-396.

124. Ruzsanyi V, Baumbach JI, Sielemann S, et al. (2005) Detection of human metabolites using multi-capillary columns coupled to ion mobility spectrometers. J Chromatogr A 1084, 145-151.

125. Moser B, Bodrogi F, Eibl G, et al. (2005) Mass spectrometric profile of exhaled breath - field study by PTR-MS. Resp Physiol Neurobiol 145, 295-300.

126. Lirk P, Bodrogi F \& Rieder J (2004) Medical applications of proton transfer reaction-mass spectrometry: ambient air monitoring and breath analysis. Int J Mass Spectrom 239, 221-226.

127. Jordan A, Haidacher S, Hanel G, et al. (2009) An online ultra-high sensitivity proton-transfer-reaction mass-spectrometer combined with switchable reagent ion capability (PTR + SRI-MS). Int J Mass Spectrom 286, 32-38.

128. Blake RS, Monks PS \& Ellis AM (2009) Proton-transfer reaction mass spectrometry. Chem Rev 109, 861-896.

129. Herbig J, Muller M, Schallhart S, et al. (2009) On-line breath analysis with PTR-TOF. J Breath Res 3, 027004.

130. Jordan A, Haidacher S, Hanel G, et al. (2009) A high resolution and high sensitivity proton-transfer-reaction time-of-flight mass spectrometer (PTR-TOF-MS). Int J Mass Spectrom 286, 122-128.

131. Wang TS (2005) The selected ion flow tube mass spectrometry and its applications to trace gas analysis. Chinese J Anal Chem 33, 887-893.

132. Španěl P, Dryahina K \& Smith D (2006) A general method for the calculation of absolute trace gas concentrations in air and breath from selected ion flow tube mass spectrometry data. Int J Mass Spectrom 249, 230-239.

133. Di Francesco F, Fuoco R, Trivella MG, et al. (2005) Breath analysis: trends in techniques and clinical applications. Microchem J 79, 405-410.

134. Thaler ER, Kennedy DW \& Hanson CW (2001) Medical applications of electronic nose technology: review of current status. Am J Rhinol 15, 291-295.

135. Sye WF \& Cheng MF (1997) The analysis of sulfur compounds by solid adsorbent Tenax GR preconcentration and gas chromatography with flameless sulfur chemiluminescence detection. J Chinese Chem Soc 44, 107-114.

136. Toda K \& Dasgupta PK (2008) New applications of chemiluminescence for selective gas analysis. Chem Eng Commun 195, 82-97.

137. Rumessen JJ, Kokholm G \& Gudmandhoyer E (1987) Methodological aspects of breath hydrogen $\left(\mathrm{H}_{2}\right)$ analysis - evaluation of a $\mathrm{H}_{2}$ monitor and interpretation of the breath $\mathrm{H}_{2}$ test. Scand J Clin Lab Invest 47, 555-560.

138. Romagnuolo J, Schiller D \& Bailey RJ (2002) Using breath tests wisely in a gastroenterology practice: an evidence-based review of indications and pitfalls in interpretation. Am J Gastroenterol 97, 1113-1126.

139. Eisenmann A, Amann A, Said M, et al. (2008) Implementation and interpretation of hydrogen breath tests. J Breath Res 2, 046002.

140. Bond JH \& Levitt MD (1971) Quantiatative measurement of carbohydrate malabsorption using respiratory hydrogen $\left(\mathrm{H}_{2}\right)$ excretion. Gastroenterology 60, 765.

141. Bond JH \& Levitt MD (1977) Use of breath hydrogen $\left(\mathrm{H}_{2}\right)$ in the study of carbohydrate absorption. Am J Dig Dis 22, 379-382.

142. Taylor D, Pijnenburg M, Smith A, et al. (2006) Exhaled nitric oxide measurements: clinical application and interpretation. Thorax 61, 817-827.

143. Stevenson DK, Fanaroff AA, Maisels MJ, et al. (2001) Prediction of hyperbilirubinemia in near-term and term infants. Pediatrics 108, 31-39.
144. Phillips M, Boehmer JP, Cataneo RN, et al. (2004) Prediction of heart transplant rejection with a breath test for markers of oxidative stress. Am J Cardiol 94, 1593-1594.

145. Endre Z, Pickering J, Storer M, et al. (2011) Breath ammonia and trimethylamine allow real-time monitoring of haemodialysis efficacy. Physiol Meas 32, 115-130.

146. Rolla G, Bruno M, Bommarito L, et al. (2008) Breath analysis in patients with end-stage renal disease: effect of haemodialysis. Eur J Clin Invest 38, 728-733.

147. Narasimhan LR, Goodman W \& Patel CKN (2001) Correlation of breath ammonia with blood urea nitrogen and creatinine during hemodialysis. Proc Natl Acad Sci U S A 98, 4617-4621.

148. Braden B, Lembcke B, Kuker W, et al. (2007) ${ }^{13}$ C-breath tests: current state of the art and future directions. Dig Liver Dis 39, 795-805.

149. Rao S, Camilleri M, Hasler W, et al. (2011) Evaluation of gastrointestinal transit in clinical practice: position paper of the American and European Neurogastroenterology and Motility Societies. Neurogastroenterol Motil 23, 8-23.

150. Geboes KP, Luypaerts A, Rutgeerts P, et al. (2003) Inulin is an ideal substrate for a hydrogen breath test to measure the orocaecal transit time. Aliment Pharmacol Ther 18, 721-729.

151. Shestivska V, Nemec A, Drevinek P, et al. (2011) Quantification of methyl thiocyanate in the headspace of Psendomonas aeruginosa cultures and in the breath of cystic fibrosis patients by selected ion flow tube mass spectrometry. Rapid Commun Mass Spectrom 25, 2459-2467.

152. Carroll W, Lenney W, Wang TS, et al. (2005) Detection of volatile compounds emitted by Psendomonas aeruginosa using selected ion flow tube mass spectrometry. Pediatr Pulmonol 39, 452-456.

153. Sanchez JM \& Sacks RD (2003) GC analysis of human breath with a series-coupled column ensemble and a multibed sorption trap. Anal Chem 75, 2231-2236.

154. Smith D, Španěl P, Thompson JM, et al. (1998) The selected ion flow tube method for workplace analyses of trace gases in air and breath: its scope, validation and applications. Appl Occup Environ Hygiene 13, 817-823.

155. Smith D \& Španěl P (1996) Application of ion chemistry and the SIFT technique to the quantitative analysis of trace gases in air and on breath. Int Rev Phys Chem 15, 231-271.

156. Smith D \& Španěl P (2005) Selected ion flow tube mass spectrometry (SIFT-MS) for on-line trace gas analysis. Mass Spectrom Rev 24, 661-700.

157. Boshier PR, Marczin N \& Hanna GB (2010) Repeatability of the measurement of exhaled volatile metabolites using selected ion flow tube mass spectrometry. J Am Soc Mass Spectrom 21, 1070-1074.

158. Oh EH, Song HS \& Park TH (2011) Recent advances in electronic and bioelectronic noses and their biomedical applications. Ensyme Microb Technol 48, 427-437.

159. Lewicki R, Wysocki G, Kosterev A, et al. (2007) Carbon dioxide and ammonia detection using $2 \mu \mathrm{m}$ diode laser based quartz-enhanced photoacoustic spectroscopy. Appl Phys B 7, 157-162.

160. Dahnke H, Kleine D, Hering P, et al. (2001) Real-time monitoring of ethane in human breath using mid-infrared cavity leak-out spectroscopy. Appl Phys B 72, 971-975.

161. Fuchs P, Loeseken C, Schubert JK, et al. (2010) Breath gas aldehydes as biomarkers of lung cancer. Int J Cancer 126, 2663-2670.

162. Henderson MJ, Karger BA \& Wrenshall GA (1952) Acetone in the breath; a study of acetone exhalation in diabetic and nondiabetic human subjects. Diabetes 1, 188-193.

163. Španěl P, Davies S \& Smith D (1998) Quantification of ammonia in human breath by the selected ion flow tube analytical method using $\mathrm{H}_{3} \mathrm{O}^{+}$and $\mathrm{O}_{2}^{+}$precursor ions. Rapid Commun Mass Spectrom 12, 763-766.

164. Rosen RT, Hiserodt RD, Fukuda EK, et al. (2000) The determination of metabolites of garlic preparations in breath and human plasma. Biofactors 13, 241-249.

165. Lawson LD \& Hughes BG (1992) Characterization of the formation of allicin and other thiosulfinates from garlic. Planta Med 58, 345-350. 
166. Lawson LD \& Gardner CD (2005) Composition, stability, and bioavailability of garlic products used in a clinical trial. J Agric Food Chem 53, 6254-6261.

167. Rosen RT, Hiserodt RD, Fukuda EK, et al. (2001) Determination of allicin, $S$-allylcysteine and volatile metabolites of garlic in breath, plasma or simulated gastric fluids. J Nutr 131, 968S-971S.

168. Phillips M (1992) Detection of carbon-disulfide in breath and air: a possible new risk factor for coronary artery disease. Int Arch Occup Environ Health 64, 119-123.

169. Ciaffoni L, Peverall R \& Ritchie GAD (2011) Laser spectroscopy on volatile sulfur compounds: possibilities for breath analysis. J Breath Res 5, 024002.

170. Chen S, Zieve L \& Mahadeva V (1970) Mercaptans and dimethy sulfide in breath of patients with cirrhosis of liver. Effect of feeding methionine. I Lab Clin Med 75, 628-635.

171. Wysocki G, McCurdy M, So S, et al. (2004) Pulsed quantumcascade laser-based sensor for trace-gas detection of carbonyl sulfide. Appl Opt 43, 6040-6046.

172. Halmer D, von Basum G, Hering P, et al. (2005) Mid-infrared cavity leak-out spectroscopy for ultrasensitive detection of carbonyl sulfide. Opt Lett 30, 2314-2316.

173. Middleton ET \& Morice AH (2000) Breath carbon monoxide as an indication of smoking habit. Chest 117, 758-763.

174. Tenhunen R, Marver HS \& Schmid R (1968) The enzymatic conversion of heme to bilirubin by microsomal heme oxygenase. Proc Natl Acad Sci U S A 61, 748-755.

175. Ryter SW, Alam J \& Choi AMK (2006) Heme oxygenase-1/carbon monoxide: from basic science to therapeutic applications. Physiol Rev 86, 583-650.

176. Paredi P, Biernacki W, Invernizzi G, et al. (1999) Exhaled carbon monoxide levels elevated in diabetes and correlated with glucose concentration in blood: a new test for monitoring the disease? Chest 116, 1007.

177. Costello B, Ewen R \& Ratcliffe N (2008) A sensor system for monitoring the simple gases hydrogen, carbon monoxide, hydrogen sulfide, ammonia and ethanol in exhaled breath. J Breath Res 2, 037001.

178. Tangerman A, Meuwesearends MT \& Vantongeren JHM (1983) A new sensitive assay for measuring volatile sulfur compounds in human breath by Tenax trapping and gas-chromatography and its application in liver cirrhosis. Clinica Chimica Acta 130, 103-110.

179. Azad M, Ohira SI \& Toda K (2006) Single column trapping/separation and chemiluminescence detection for on-site measurement of methyl mercaptan and dimethyl sulfide. Anal Chem 78, 6252-6259.

180. Paredi P, Kharitonov SA, Leak D, et al. (2000) Exhaled ethane, a marker of lipid peroxidation, is elevated in chronic obstructive pulmonary disease. Am J Respir Crit Care Med 162, 369-373.

181. Dillard CJ, Dumelin EE \& Tappel AL (1977) Effect of dietary vitamin E on expiration of pentane and ethane by rat. Lipids 12, 109-114.

182. Dumelin EE \& Tappel AL (1977) Hydrocarbon gases produced during in vitro peroxidation of polyunsaturated fatty acids and decomposition of preformed hydroperoxides. Lipids 12, 894-900.

183. Dumitras DC, Giubileo G \& Puiu A (2005) Investigation of human biomarkers in exhaled breath by laser photoacoustic spectroscopy. Proc SPIE 5850, 111-121.

184. Perman JA, Modler S, Barr RG, et al. (1984) Fasting breath hydrogen concentration: normal values and clinical application. Gastroenterology 87, 1358-1363.

185. Christl SU, Murgatroyd PR, Gibson GR, et al. (1992) Production, metabolism, and excretion of hydrogen in the large intestine. Gastroenterology 102, 1269-1277.

186. Lundquist P, Rosling H \& Sorbo B (1988) The origin of hydrogen cyanide in breath. Arch Toxicol 61, 270-274.

187. Španěl P, Dryahina K \& Smith D (2007) Acetone, ammonia and hydrogen cyanide in exhaled breath of several volunteers aged 4 83 years. J Breath Res 1, 011001

188. Enderby B, Smith D, Carroll W, et al. (2009) Hydrogen cyanide as a biomarker for Pseudomonas aeruginosa in the breath of children with cystic fibrosis. Pediatr Pulmonol 44, 142-147.
189. Gelmont D, Stein RA \& Mead JF (1981) Isoprene: the main hydrocarbon in human breath. Biochem Biophys Res Commun 99, 1456-1460.

190. Karl T, Prazeller P, Mayr D, et al. (2001) Human breath isoprene and its relation to blood cholesterol levels: new measurements and modeling. J Appl Pbysiol 91, 762-770.

191. Stone BG, Besse TJ, Duane WC, et al. (1993) Effect of regulating cholesterol biosynthesis on breath isoprene excretion in men. Lipids 28, 705-708.

192. Jones AW, Lagesson V \& Tagesson C (1995) Origins of breath isoprene. J Clin Pathol 48, 979-980.

193. Davies S, Španěl P \& Smith D (2001) A new 'online' method to measure increased exhaled isoprene in end-stage renal failure. Nephrol Dial Transplant 16, 836-839.

194. Taucher J, Hansel A, Jordan A, et al. (1997) Detection of isoprene in expired air from human subjects using proton-transfer-reaction mass spectrometry. Rapid Commun Mass Spectrom 11, 1230-1234.

195. Dryahina K, Smith D \& Španěl P (2010) Quantification of methane in humid air and exhaled breath using selected ion flow tube mass spectrometry. Rapid Commun Mass Spectrom 24, 1296-1304.

196. Rumessen JJ (1992) Hydrogen and methane breath tests for evaluation of resistant carbohydrates. Eur J Clin Nutr 46, S77-S90.

197. Rumessen JJ, Nordgaardandersen I \& Gudmandhoyer E (1994) Carbohydrate malabsorption - quantification by methane and hydrogen breath tests. Scand J Gastroenterol 29, 826-832.

198. Sahakian AB, Jee SR \& Pimentel M (2010) Methane and the gastrointestinal tract. Dig Dis Sii 55, 2135-2143.

199. Miller TL, Wolin MJ, Demacario EC, et al. (1982) Isolation of Methanobrevibacter smitbii from human feces. Appl Environ Microbiol 43, 227-232.

200. Marinov D, Rey JM, Mueller MG, et al. (2007) Spectroscopic investigation of methylated amines by a cavity-ringdown-based spectrometer. Appl Opt 46, 3981-3986.

201. Novak BJ, Blake DR, Meinardi S, et al. (2007) Exhaled methyl nitrate as a noninvasive marker of hyperglycemia in type 1 diabetes. Proc Natl Acad Sci U S A 104, 15613-15618.

202. Paredi P, Ward S, Cramer D, et al. (2007) Normal bronchial blood flow in COPD is unaffected by inhaled corticosteroids and correlates with exhaled nitric oxide. Chest 131, 1075-1081.

203. Paredi P, Kharitonov SA \& Barnes PJ (2001) Direct methods for the measurement of nitric oxide. Monaldi Arch Chest Dis 56, 88-90.

204. American Thoracic Society Workshop (2006) ATS workshop proceedings: exhaled nitric oxide and nitric oxide oxidative metabolism in exhaled breath condensate: executive summary. Am J Respir Crit Care Med 173, 811-813.

205. Lundberg JON, Weitzberg E, Lundberg JM, et al. (1996) Nitric oxide in exhaled air. Eur Respir J 9, 2671-2680.

206. Lundberg J (1996) Airborne nitric oxide: inflammatory marker and aerocrine messenger in man. Acta Physiol Scand Suppl 157, 1-27.

207. Hibbs JB (1991) Synthesis of nitric oxide from L-arginine: a recently discovered pathway induced by cytokines with antitumor and antimicrobial activity. Res Immunol 142, 565-569.

208. Hibbs JB, Westenfelder C, Taintor R, et al. (1992) Evidence for cytokine-inducible nitric oxide synthesis from L-arginine in patients receiving interleukin-2 therapy. J Clin Invest 89, 867-877.

209. Silkoff PE, McClean PA, Slutsky AS, et al. (1997) Marked flowdependence of exhaled nitric oxide using a new technique to exclude nasal nitric oxide. Am J Respir Crit Care Med 155, 260-267.

210. Cobos Barroso N, Perez-Yarza EG, Sardon Prado O, et al. (2008) Exhaled nitric oxide in children: a noninvasive marker of airway inflammation (article in Spanish). Arch Bronconeumol 44, 41-51.

211. Olopade CO, Zakkar M, Swedler WI, et al. (1997) Exhaled pentane levels in acute asthma. Chest 111, 862-865.

212. Lewis GD, Laufman AK, Mcanalley BH, et al. (1984) Metabolism of acetone to isopropyl alcohol in rats and humans. J Forensic $S_{c i}$ 29, 541-549.

213. Warneke C, Kuczynski J, Hansel A, et al. (1996) Proton transfer reaction mass spectrometry (PTR-MS): propanol in human breath. Int J Mass Spectrom 154, 61-70. 